Pontifícia Universidade Católica do Rio de Janeiro

Marketing olfativo: A utilização de uma identidade olfativa como estratégia para conquistar um espaço duradouro na cabeça dos consumidores

Tanya de Oliveira Davies

Trabalho de Conclusão de Curso

Centro de Ciências Socials - CCS

DePARTAMENTO de AdMINISTRAÇÃO

Graduação em Administração de Empresas 


\section{Marketing olfativo: A utilização de uma identidade olfativa como estratégia para conquistar um espaço duradouro na cabeça dos consumidores}

Trabalho de Conclusão de Curso

Trabalho de Conclusão de Curso, apresentado ao programa de graduação em Administração da PUC-Rio como requisito parcial para a obtenção do titulo de graduação em Administração.

Orientador: Daniel Kamlot 
"Perfume is the most intense form of memory" Jean Paul Guerlain 


\section{Agradecimentos}

Primeiramente, agradeço a Deus pela minha vida e por Ele ter me abençoado com uma boa saúde, pais maravilhosos e amigos incríveis.

Agradeço aos meus pais, Lenora de Oliveira e Roy Davies, meu portoseguro, por todo seu apoio incondicional; por terem me dado a educação que eu tenho; por serem meus melhores amigos e também por sempre acreditarem em mim, não deixando que eu desistisse nunca. Sem vocês, nada disso seria possível.

Agradeço também ao meu avô, Guilherme Hupsel, que infelizmente não está mais fisicamente conosco, mas que sempre esteve ao meu lado e que tenho certeza de que estará sempre torcendo por mim, onde quer que esteja.

Um agradecimento especial a todos meus amigos, que tornam a jornada da vida mais prazerosa e divertida. Obrigada pelo apoio em todos os momentos, pela compreensão e por serem minha segunda família.

Agradeço ao meu namorado, Vinicius Ferreira, pelo seu incentivo, por me sempre encorajar e me fazer acreditar que tudo é possível.

E, por fim, agradeço a todos os professores com quem tive a honra de conviver ao longo desses últimos anos, que tanto me ensinaram e por quem eu sou eternamente grata. Um agradecimento especial ao meu orientador Daniel Kamlot, pela paciência, pelo seu jeito calmo, compreensivo e sempre atencioso. 


\section{Resumo}

Davies, Tanya de O. Marketing Olfativo: a utilização de uma identidade olfativa como estratégia para conquistar um espaço duradouro na cabeça dos consumidores. Rio de Janeiro, 2015. Número de páginas p. 65 Trabalho de Conclusão de Curso - Departamento de Administração. Pontifícia Universidade Católica do Rio de Janeiro.

Não é novidade que o setor varejista possui inúmeros concorrentes. Este fato faz com que alguns lojistas tenham a necessidade de se diferenciar dos demais, utilizando-se de várias estratégias de marketing, que visam atrair os consumidores para seus pontos de venda. Tendo isso em vista, o presente trabalho tem como objetivo explicar a utilização da técnica de aromatização pelos varejistas como forma de criar um ambiente agradável e propício ao consumo, e ao mesmo tempo, fazer com que cada marca possua uma identidade olfativa que será "memorizada" pela clientela. Para tal, foi realizado um teste cego com 108 clientes de lojas selecionadas com o intuito de averiguar se a identidade olfativa dessas lojas está presente em sua memória olfativa. Para auxiliar na elaboração do questionário, foram realizadas conversas informais com gerentes de quatros lojas de varejo de vestuário feminino que relataram o feedback obtido de suas clientes sobre o "cheirinho" da loja e se, de fato, a estratégia de aromatização é tão eficiente quanto as demais.

\section{Palavras- chave}

Marketing olfativo; Comportamento do consumidor, Marketing Sensorial e Varejo. 


\section{Abstract}

Davies, Tanya de O. Scent Marketing: the use of an olfactory identity as a strategy to achieve a lasting space in the minds of consumers. Rio de Janeiro, 2015. Number of pages p. 65 Coursework Completion Paper - Management Department. Pontifical Catholic University of Rio de Janeiro.

It is no novelty that the retail sector has numerous competitors. This fact has caused some retailers to have the need to differentiate themselves from others by using various marketing strategies that aim to attract consumers to their selling points. With this in mind, this paper aims to explain the use of a scent technique by retailers as a way to create an environment that is both pleasant and conducive to consumption, while, at the same time, making each brand have an olfactory identity that will be "memorized" by the clientele. To this end, I conducted a blind test with 108 customers of selected stores in order to ascertain whether the olfactory identity of those stores is present in the customers' olfactory memory. To assist in the preparation of the questionnaire, informal talks were held with four managers of women's apparel retail stores who provided me with the feedback they got from their customers on the stores' "scent", and whether the scent strategy was in fact as efficient as the others.

Key-words

Scent Marketing; Consumer Behaviour; Brandsense and Retail 


\section{Sumário}

1 O problema 1

1.1. Introdução 1

1.2. Objetivo Final 2

1.3. Objetivos Intermediários 2

1.4. Delimitação do estudo 2

1.5. Relevância do estudo 3

2 Referencial Teórico 4

2.1. Marketing de Varejo 4

2.1.1. Apresentação, atmosfera e ambiente da loja 6

2.2. Marketing Sensorial (Brandsense) 7

2.3. Neuromarketing 12

2.4. Comportamento do Consumidor 15

2.5. O Marketing Olfativo cria uma Identidade Olfativa 17

$\begin{array}{ll}\text { 2.5.1. Identidade Olfativa } & 20\end{array}$

2.5.2. Desenvolvimento da Identidade Olfativa 21

2.6. Aromaterapia 22

2.7. O mercado da indústria do "cheiro" no Brasil 23

2.7.1. A estratégia da venda pelo "cheiro" 27

2.8. Cases de Sucesso 31

2.9. Curiosidades 33

3 Metodologia 35

3.1. Tipo de Pesquisa 35

3.1.1. Quanto aos Fins 35

3.1.2. Quantos aos Meios 35

3.2. Universo e Amostra 35

3.3. Seleção dos sujeitos 36

3.4. Coleta de Dados 36

$\begin{array}{ll}\text { 3.5. Tratamento dos dados } & 37\end{array}$ 
4 Apresentação e análise dos resultados 38

4.1. Descrição dos resultados 38

4.1.1. Lojas com "cheiros" marcantes 38

4.1.2. Preferência de lojas para compras 39

4.1.3. Reconhecimento do aroma 40

4.1.4. Resultados do Teste Cego 41

4.1.5. Número de cheiros que as respondentes acertaram 42

4.1.6. Lojas que foram mais reconhecidas 43

4.1.7. Percepção das respondentes com relação aos cheiros 44

4.1.8. Opinião sobre o cheiro das lojas 45

4.1.9. Sensações que o cheiro da loja desperta nas pessoas 46

4.1.10. Compraria o aroma de uma das lojas apresentadas? De quais lojas? $\quad 47$

4.1.11. O que acha da estratégia das lojas em aromatizarem seus pontos de venda 48

4.1.12. Idade 49

4.2. Análises Cruzadas $\quad 50$

4.2.1. Acha que seria capaz de reconhecer os cheiros $x$ quantos cheiros acertou $\quad 50$

4.2.2. Onde mais compra $x$ capacidade de percepção das pessoas com relação aos cheiros 53

4.2.3. Quantos cheiros acertou x reação pessoal ao cheiro 54

5 Conclusões e recomendações para novos estudos 56

5.1. Sugestões e recomendações para novos estudos 58

6 Referências Bibliográficas $\quad 59$

Anexo 1 - Questionário 62 


\section{Lista de figuras}

Figura 1: Importância relativa dos estímulos sensoriais............................10

Figura 2: Etapas do sistema límbico..........................................................11

Figura 3: As ferramentas das Cores.........................................................13

Figura 4: Modelo de Processo de Compra do Consumidor......................... 16

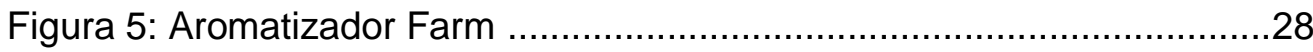

Figura 6: Aromatizador Maria Filó..............................................................29

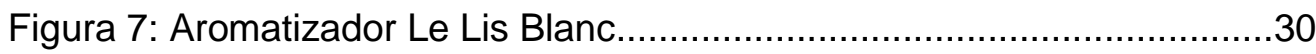

Figura 8: Aromatizador Cantão............................................................ 31

Figura 9: Aromas para teste cego...................................................37

\section{Lista de Tabelas}

Tabela 1: Opções escolhidas.

Tabela 2: Análise cruzada dos resultados entre "onde mais compra" e

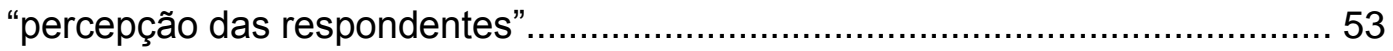

Tabela 3: Análise cruzada dos resultados entre "quantos cheiros acertou" e "reação pessoal ao cheiro". .55

\section{Lista de Gráficos}

Gráfico 1: Resultado referente à "Q1: Quando você pensa no "cheiro das lojas" alguma das marcas abaixo lhe vêm à cabeça?"

Gráfico 2: Resultado referente à "Q2: Marque onde você mais compra"..... 40

Gráfico 3: Resultado referente à "Q3: Acha que seria capaz de reconhecer o cheiro das lojas onde compra, mesmo não estando lá?"

Gráfico 4: Número de cheiros acertados.......................................................4

Gráfico 5: Lojas que tiveram aroma mais reconhecido ...................................43 
Gráfico 6: Percepção dos respondentes em relação ao cheiros 45

Gráfico 7: Opinião dos respondentes sobre o cheiro das lojas 45

Gráfico 8: Sensações que o cheiro da loja desperta nas pessoas ................... 46

Gráfico 9: Frequência de pessoas que compraria o aroma da loja .................. 47

Gráfico 10: Lojas mais escolhidas pelas pessoas para compra do aroma ....... 48

Gráfico 11: Opinião das respondentes sobre a estratégia do marketing olfativo.49

Gráfico 12: Idade . .49

Gráfico 13: Análise cruzada: Escolha da opção SIM ..................................... 50

Gráfico 14: Análise cruzada: Escolha da opção NÃO ................................... 51

Gráfico 15: Análise Cruzada: escolha da opção NÃO SEI ................................ 52 


\section{0 problema}

\subsection{Introdução}

Quem não gosta de chegar numa loja e sentir um aroma que evoque uma sensação de aconchego e bem-estar? Ou sentir aquele cheirinho de grama molhada após a chuva, pão quentinho saindo do forno, cheiro de café, de carro novo e até mesmo da pipoca do cinema? Hoje, graças à tecnologia e a necessidade de diferenciar muitas empresas recorrem ao marketing olfativo que utiliza um appeal que supera o visual no que diz respeito à atração de clientes para o consumo. Isso porque, segundo a perfumista especializada em marketing olfativo, Fátima Leão Farkas (2013, p. 14), "os odores têm essa propriedade: eles marcam a nossa memória e, uma vez acionados, desencadeiam uma série de sensações e recordações".

Sabemos que as empresas se utilizam de inúmeras estratégias para atrair seus consumidores e, pensando nisso, o marketing olfativo, que está cada vez mais sendo utilizado pelo varejo visa atrair consumidores pela identificação que estes estabelecem com o aroma das lojas, identificando-as de imediato. Uma marca pode ser vendida através de uma experiência sensorial que vai além do estímulo auditivo e visual. Cheiros nos afetam mais do que imaginamos! Os psicólogos Pieter Aarts e J.Stephan Jellinek, experts em fragrâncias, estudaram como cheiros, de forma subconsciente, influenciam a opinião, sentimentos e o comportamento das pessoas. Eles descobriram que uma fragrância pode determinar que uma pessoa compre, colecione ou até use um produto. Uma essência marcante pode nos despertar sensações e lembranças agradáveis que ficarão registradas em nossa memória, fazendo-nos querer senti-las novamente! E é nesses conceitos que alguns lojistas se baseiam quando visam criar uma identidade olfativa para seus pontos de venda. O marketing olfativo e sua relação com o varejo pode indicar se o cheiro seria capaz de fisgar o cliente, fazendo com que ele permaneça mais tempo na loja e, dessa forma, consumindo mais. E o mais importante - o cliente sempre volta onde se sente bem!

Graças a avanços tecnológicos e à busca por um diferencial, inúmeros tipos de aromas podem ser artificialmente produzidos por empresas especializadas e 
vendidos para lojas. Essas empresas especializadas criam aromas exclusivos e personalizados, conforme o conceito e a proposta da marca. O aroma escolhido, muitas vezes, é de tal forma envolvente, que a loja aproveita-se desse fato para, paralelamente, vendê-lo para o cliente, por meio de sprays e difusores. Dessa forma, o cliente acaba criando uma memória olfativa que o faz lembrar-se da loja. A tendência será que ele volte e consuma novamente nessa loja.

Portanto, este trabalho visa responder à seguinte questão: A utilização de uma identidade olfativa por uma loja como estratégia conquista um espaço duradouro na memória dos consumidores?

\subsection{Objetivo Final}

Este trabalho tem como objetivo avaliar se a utilização de uma identidade olfativa como estratégia conquista um espaço duradouro na memória dos consumidores, o que poderá remetê-los à lembrança da marca.

\subsection{Objetivos Intermediários}

Para se atingir o objetivo final proposto, alguns objetivos intermediários devem ser alcançados:

- Analisar de que forma funcionam as empresas do setor de marketing olfativo.

- Identificar a estratégia utilizada pelas empresas de marketing olfativo junto a algumas lojas do setor de varejo para a criação de uma identidade olfativa da marca.

- Investigar de que forma os consumidores reagem a essa estratégia.

\subsection{Delimitação do estudo}

O estudo está delimitado a mulheres residentes no estado do Rio de Janeiro, com idade maior ou igual a 18 anos.

Para poder avaliar o impacto do aroma no setor de varejo, as lojas escolhidas para o estudo foram Cantão, Farm, Maria Filó e Le Lis Blanc.

Essas lojas são adequadas para o estudo, visto que são lojas voltadas especificamente ao público feminino e que possuem um aroma específico 
marcante. Isso denota uma intenção de captar e até mesmo fidelizar os clientes através desse aroma.

\subsection{Relevância do estudo}

Este estudo pode ser considerado relevante para as empresas do setor de varejo que desejam investigar se seus consumidores se sentem ou não atraídos pelos aromas que as identificam, fidelizando-se a elas, aumentando sua intenção de compra e, consequentemente, o aumento de vendas das marcas.

Com base no resultado do estudo, as empresas que ainda não utilizam essa importante ferramenta de marketing poderão ser intuídas a utilizá-la, para alavancar suas vendas. 


\section{Referencial Teórico}

\subsection{Marketing de Varejo}

O varejo é definido como todas as atividades relativas à venda de produtos ou serviços diretamente ao consumidor final, para uso pessoal e não comercial. (KOTLER, 2000).

De acordo com Parente (2007, p.22) "o varejista faz parte dos sistemas de distribuição entre o produtor e o consumidor, desempenhando um papel de intermediário, funcionando como um elo entre o nível do consumo e o nível do atacado ou da produção. Apesar de exercerem uma função de intermediários, assumem cada vez mais um papel pró-ativo na identificação das necessidades do consumidor e na definição do que deverá ser produzido para atender às expectativas do mercado".

O varejo possui algumas funções, de acordo com Bernardino (2011) apud Levy e Weitz (2011). Algumas delas são:

- Fornecer uma variedade de produtos e serviços

- Dividir lotes grandes em pequenas quantidades

- Manter estoques

- Fornecer serviços

Cada uma dessas funções tem sua importância, pois os consumidores passam a perceber que os produtos e serviços dos varejistas com um olhar mais apurado, aumentando dessa forma sua percepção de valor.

Satisfazer as necessidades e os desejos dos consumidores, entendendo suas motivações e criando valor para eles, é algo que os profissionais de marketing estão sempre em busca, mas ainda de acordo com Bernardino apud Berman e Evans (2010) o varejo apresenta três objetivos que visam complementar sua estratégia, sendo eles: 
- Atingir um determinado volume de vendas

- Atingir um determinado nível de lucratividade

- Criar e manter uma imagem apropriada ao tipo de negócio em questão

Parente (2007) ainda acrescenta mais alguns objetivos do varejo, entre eles:

- Número de clientes - esse objetivo influencia diretamente o volume de vendas da loja. Para aumentar o número de clientes que visitam a loja em certo período, os varejistas ampliam seus esforços em propaganda e promoção de vendas.

- Lealdade do consumidor - conquistar a fidelidade do cliente e conseguir $100 \%$ de sua preferência é um objetivo que ajudará o aumento das vendas.

- Satisfação do cliente - o aumento da satisfação, ou sua diminuição, poderá repetidamente sinalizar oportunidades ou ameaças para os varejistas.

Para que esses objetivos sejam alcançados os varejistas precisam antes de tudo conhecer o seu mercado-alvo, pois é baseado neste mercado que os varejistas vão adotar decisões de marketing para suas lojas, tais como o sortimento de seus produtos, a decoração da loja, a mídia, a propaganda, os preços. Ao conhecer o seu mercado-alvo, seus gostos e preferências, a tendência é que seja formulado um mix de marketing que atraia os consumidores para a loja e, dessa forma, eles se tornem clientes fiéis.

Um aspecto interesse que deve-se levar em conta é o comportamento adaptativo dos varejos, pois a cada hora surgem novas necessidades do mercado que devem ser atendidas e, portanto, os varejos têm de se adaptar a essas necessidades. Segundo Parente (2007) qualquer varejista precisa estar permanentemente alerta e pronto para adaptar-se aos constantes desafios da concorrência, às ameaças ambientais e às novas oportunidades de mercado. Para isso deverão estar em permanente processo de melhoria contínua, utilizando o mais avançado ferramental tecnológico, gerencial e mercadológico, para simultaneamente conseguirem conquistar a satisfação dos clientes e minimizar seus custos operacionais. 
Portanto, "o marketing de varejo é o marketing realizado pelo varejista, visando aumentar as vendas, a participação de mercado e a percepção positiva do seu empreendimento como um todo, aumentando, também, a fidelidade de seus clientes". (BERNARDINO, 2011, p.13).

\subsubsection{Apresentação, atmosfera e ambiente da loja}

Os varejistas sabendo que precisam conquistar os consumidores atraindo-os para seu ponto de venda e, ao mesmo tempo, precisam se diferenciar dos seus concorrentes apostam grande parte de suas decisões justamente na loja, investindo em elementos como a atmosfera e ambiente. Isso porque a combinação de um ambiente agradável com disposição dos consumidores para compra aumenta a chance de que eles permaneçam no ambiente, fazendo com que tenham uma propensão maior a comprar.

Entre as várias exigências para o bom desempenho comercial de um estabelecimento de varejo, destacam-se algumas unidades básicas, entre elas 0 layout das lojas, incluindo as considerações relativas à distribuição das seções, arranjos físicos e decoração, iluminação e outros aspectos. Aspectos como a divulgação interna e externa; a exposição de mercadorias, inclusive vitrinismo e demonstrações e ofertas diretas ao consumidor (MIRANDA, 1997). É importante que os varejistas tenham seu posicionamento e seu mercado-alvo bem definidos para que consigam criar a identidade da loja.

A atmosfera do varejo, portanto, "deve ser entendida como o sentimento psicológico que o varejista desenvolve no consumidor quando ele visita a loja. É também entendida como a personalidade da loja." (PARENTE, 2007, p.294). Portanto, é composta por elementos que são capazes de influenciar na percepção dos consumidores. Por isso, o setor de varejo está sempre fazendo modificações para se captar mais ainda a atenção dos consumidores, pois é na loja onde o consumidor manifesta seu comportamento de compra e desenvolve sua atitude e seu grau de satisfação para com o varejista. (PARENTE, 2007). Dessa forma, para influenciar os consumidores e criar a atmosfera da loja os varejistas "utilizam recursos que influenciam a visão e os outros sentidos do cliente." (PARENTE, 2007,p.294). 
Há uma série de decisões como tamanho da loja, disposição dos produtos, esquema de cores, sons, odores, layout, iluminação que devem estar de acordo com o posicionamento dos varejistas e com o mercado-alvo escolhido. Isto, porque as decisões de layout, apresentação e atmosfera devem motivar os consumidores a passar o maior tempo possível na loja, fazendo com que eles visitem mais de um setor.

O ambiente externo da loja chama atenção dos consumidores, primeiramente, pois antes mesmo de entrarem no local eles já formam uma sua primeira impressão sobre o que veem. Muitas vezes é difícil alterar a primeira impressão que os consumidores têm, por isso, investir em aspectos visuais, como a fachada da loja, arquitetura, vitrines, acabamento, iluminação são fatores que despertam o interesse das pessoas em conhecer o local. Dessa forma, "devido a uma concorrência mais acirrada, uma fachada e uma apresentação externa bem desenvolvidas podem significar uma substancial vantagem competitiva, pois são elementos que determinam não só a capacidade de atrair novos clientes, mas também são fatores relevantes para reter os consumidores atuais." (PARENTE, 2007, p. 294).

Após conseguir captar a atenção do consumidor para o ponto de venda é necessário envolvê-lo naquele novo mundo. Para isso, o ambiente interno da loja deve refletir e reforçar a boa imagem que o ambiente externo causou. $A$ apresentação externa e interna da loja devem andar de mãos dadas, pois é necessário que transmitam harmonia entre si. Nesse quesito entram em cena elementos que vão mexer com os sentidos dos consumidores. Uma boa iluminação, cores, som, cheiros, apelo ao tato são algumas dimensões trabalhadas para formar a imagem interna da loja despertando a atenção dos consumidores. Essa concepção de imagem da loja é vital para os varejistas, pois é justamente isso que fica na cabeça do consumidor e pode influenciar nos seus sentidos. Entra em cena o marketing sensorial, que baseado no neuromarketing auxilia os varejistas a formularem essas estratégias que captem o consumidor.

\subsection{Marketing Sensorial (Brandsense)}

Muito se fala sobre a importância das empresas em adotar uma série de estratégias para atrair a atenção dos consumidores. Por conta disso, as 
empresas vêm investindo no marketing sensorial, em que "elas depositam especial atenção ao impacto das sensações em nossas experiências com o produto". (SOLOMON, 2011, p.84).

De acordo com Schmitt (1999, p. 99), “o marketing sensorial apela para os cinco sentidos: visão, audição, olfato, paladar e tato. Seu objetivo geral é fornecer prazer estético, excitação, beleza e satisfação através dos estímulos sensoriais". Ele se aproveita da percepção para obter vantagem competitiva. O autor ainda cita uma tipologia de marketing denominada como "marketing aesthetics" que pode ser definido como o marketing de experiências sensoriais numa empresa ou na produção de uma marca que contribui com a identidade da empresa ou da marca. A identidade visual de uma marca é geralmente o componente mais importante que invoca atitudes, associações e respostas dos consumidores. A experiência sensorial que frequentemente atrai o consumidor para a loja deve fazer parte nas decisões estratégicas da marca. Já Lindstrom (2008), ressalta que hoje em dia as pessoas são muito estimuladas visualmente como nunca estiveram antes e que estudos confirmam que quanto mais estimulados nós estamos, mais difícil é capturar nossa atenção. Por isso, ele acredita que utilizar cheiros e sons, por exemplo, é muito mais eficiente e fácil de ser lembrado quando atuam juntos do que a pessoa ser exposta apenas a uma imagem.

Para a professora Aradhna Krishna (2009), da Universidade de Michigan, o marketing sensorial envolve os sentidos dos consumidores e afeta o seu comportamento. Isto ocorre porque os estímulos sensoriais afetam não só o modo como as pessoas se sentem, mas o que pensam, do que lembram, do que gostam e até mesmo como fazem a escolha dos produtos.

De acordo com Solomon (2011,p.83), “a sensação está relacionada com a reação imediata de nossos receptores sensoriais a estímulos básicos, como a luz, a cor, o som, os odores e as texturas. E a percepção é o processo pelo qual as pessoas selecionam, organizam e interpretam essas sensações".

Todas as pessoas passam por um processo perceptivo que consiste em receber estímulos sensoriais externos, e através dos receptores sensoriais internos (olhos, ouvidos, nariz, boca, pele), ficam expostas, fazendo com que isso atraia sua atenção e consequentemente interpretem aqueles estímulos 
externos. Os sentidos das pessoas ajudam a decidir quais produtos as atraem e quais deles se destacam dentre as muitas ofertas no mercado.

A qualidade sensorial única de um produto pode desempenhar um papel importante ao destacá-lo dos concorrentes, especialmente quando a marca cria uma associação única com a sensação. As reações são uma parte importante do consumo hedônico, os aspectos multissensoriais, fantasiosos e emocionais das interações dos consumidores com os produtos. (SOLOMON, 2011).

A comunicação entre as marcas e os consumidores funciona da seguinte forma: as marcas chamam a atenção dos consumidores através de estímulos que serão notados e processados por eles, gerando uma reação. Esses estímulos são recebidos através dos sentidos de visão, audição, olfato, tato e paladar. Esses cinco sentidos constituem a base da criação de sensações e emoções que levarão a certos comportamentos. No marketing sensorial, o poder dos sentidos é utilizado como uma forma de comunicação com os consumidores.

De acordo com um estudo realizado pela agência Millward Brown e pelo autor Lindstrom (2005) sobre o uso dos sentidos, publicado em Brand Sense, consumidores indicaram quais seriam os sentidos mais importantes no reconhecimento das marcas. De acordo com eles, a visão seria o sentido mais importante (58\%), seguido pelo olfato (45\%), audição (41\%), paladar (31\%) e tato (25\%). 
Figura 1: Importância relativa dos estímulos sensoriais

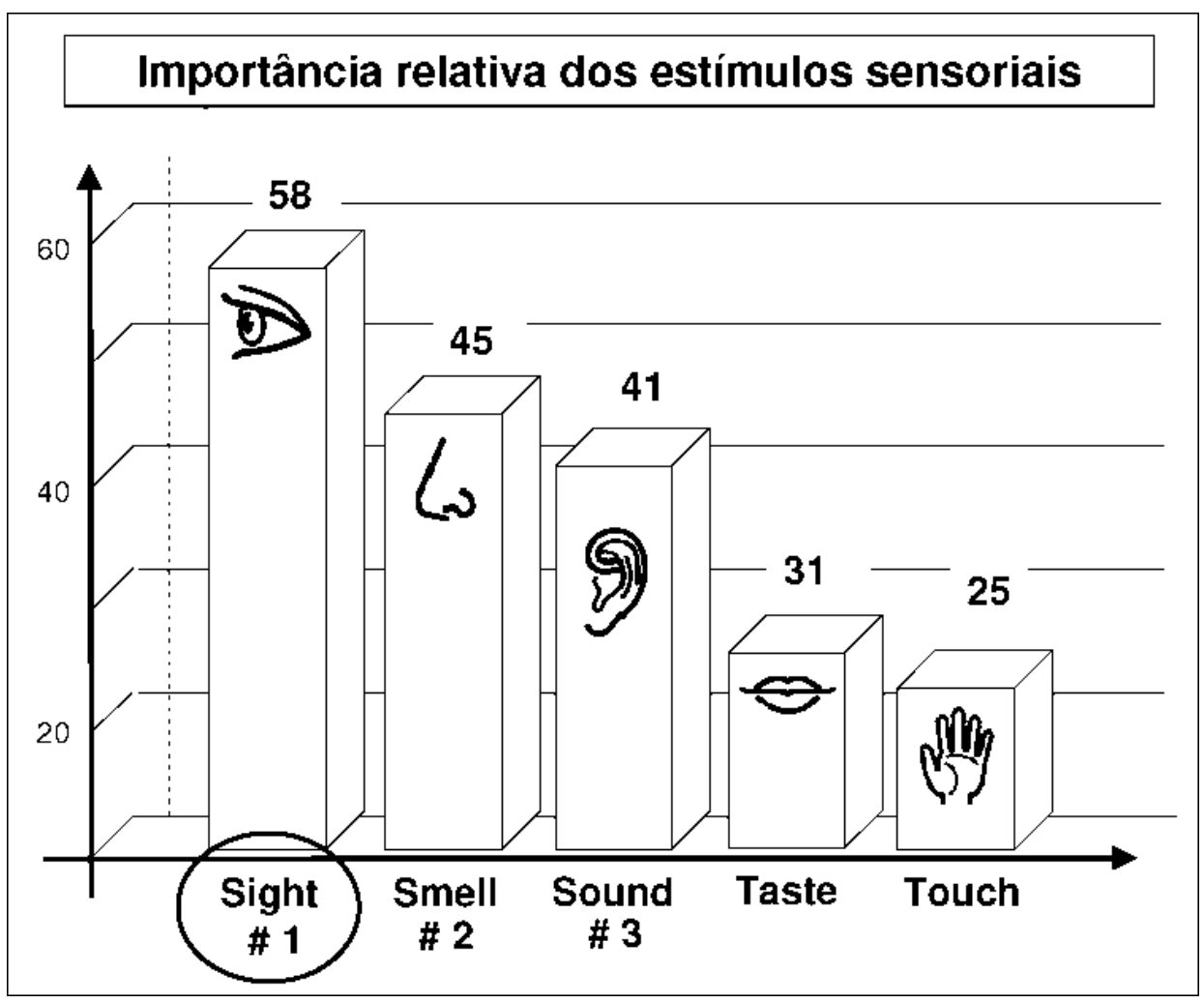

Fonte: Copyright (c) 2011 by Pedro Ferreira (Professor de Comportamento do Consumidor)

Nossa primeira constatação é de que a visão seria o sentido mais valorizado na percepção das marcas. No entanto, isto pode ser o resultado da quantidade de estímulos visuais que os consumidores recebem. Se muitos estímulos visuais são oferecidos aos consumidores, eles poderão pensar nesse sentido como o mais importante. No entanto, o mesmo estudo apresenta uma pontuação diferente no quesito "lealdade à marca", gerando um resultado diferente. Nesse estudo, o sentido "visão" teve a menor pontuação (7\%), contra tato (8\%), audição (10\%), olfato (13\%) e paladar (19\%). Chegamos à conclusão de que outros estímulos têm um impacto mais acentuado do que o estímulo visual no envolvimento dos consumidores com as marcas. A professora de marketing da Universidade da Georgia, Pam Scholder Ellen (2007) afirma: "todos os outros sentidos, você pensa antes de responder, mas com o aroma o seu cérebro responde antes de você pensar".

Quando o assunto é envolver os consumidores, aumentando sua fidelização a uma marca, o cheiro tem se revelado como um estímulo de maior impacto. Em 
1990, o Dr. Hirsch, da Smell \& Taste Research Foundation (Fundação de Pesquisa e Tratamento do Olfato e do Paladar), conduziu uma pesquisa na qual $84 \%$ dos entrevistados estariam mais inclinados a comprar um par de tênis Nike em uma loja aromatizada do que numa loja sem aromatização, de acordo com a publicação da empresa Biomist.

Pode-se dizer que a aromatização de lojas é uma técnica utilizada pelo comércio para "enganar o cérebro" dos consumidores e fazer com que eles consumam mais. Através do cheiro, uma área do nosso cérebro é acessada, chamada sistema límbico. Segundo Trucom (2015), o "Sistema Límbico, uma espécie de central emocional, pode ser considerado como o Coração da Mente". Ainda segundo a escritora, o Sistema Límbico "é responsável por regular os sentimentos, as emoções, as memórias, o aprendizado e a energia física. A absorção dos aromas através do Sistema Límbico dispara neuroquímicos específicos que podem ter ação sedativa, relaxante, estimulante, ou mesmo euforia". Em outras palavras, o sistema límbico é o local onde os odores são processados e consequentemente onde as emoções imediatas são vivenciadas. Concluímos, então, que cheiros interferem diretamente no comportamento humano e na sua expressão emocional.

Segundo Solomon (2011,p. 89) "os odores podem incitar emoções ou criar uma sensação de tranquilidade. Eles podem evocar recordações ou aliviar o estresse".

Figura 2: Etapas do sistema límbico
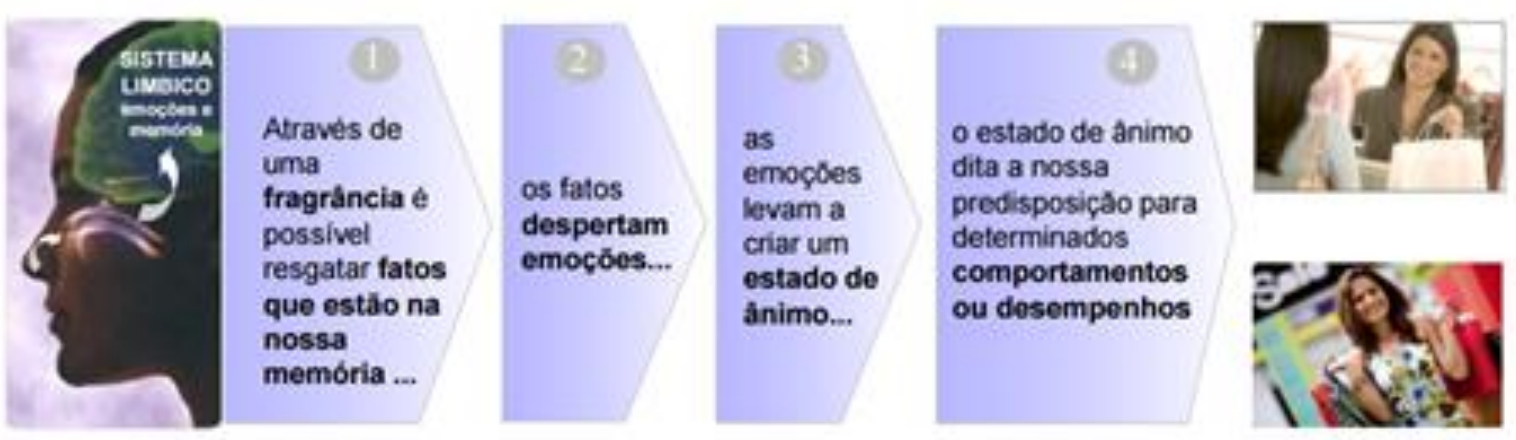

(Fonte: Apresentação Airomas)

Lenzi (2014), menciona que "há uma forte ligação entre o cérebro e o olfato e o poder de despertar sentimentos e recordar memórias além das 
barreiras da razão; por isso há um número crescente de empresas que baseiam a sua imagem em uma fragrância, graças à colaboração dos perfumistas e laboratórios que criam a essência perfeita". Perfumar uma loja significa então, a criação de um local mais confortável e convidativo onde os clientes irão passar mais tempo e criar uma boa memória que os estimulará a voltar e consumir mais. A aromatização de lojas é, portanto, uma estratégia utilizada pelo neuromarketing. Mas o que é o neuromarketing?

\subsection{Neuromarketing}

Conforme postado em seu blog, Mayra Corrêa e Castro, 2014, aromaterapeuta e profissional de Marketing, diz que "Martin Lindstrom é o maior divulgador do chamado neuromarketing". Após o enorme sucesso obtido com seu já citado livro Brand Sense, onde ele aborda as técnicas do marketing sensorial, em 2008 Lindstrom lançou "A Lógica do Consumo", e, posteriormente, em 2011, ele lançou o livro Brandwashed palavra que soa como uma insinuação a "brainwashed" (submetido à lavagem cerebral) onde, segundo Mayra (2014), Lindstrom "revela as estratégias que a publicidade usa para enganar a mente do consumidor e persuadi-lo".

Por volta dos anos 1990, muitas empresas conduziram pesquisas visando a explicar por que uma pessoa escolhe certo produto ao invés de outros do mesmo seguimento e se lembra dos detalhes de uma determinada propaganda, mas se esquece de outras que tentam vender produtos e serviços da mesma linha do varejo. Essas pesquisas levaram ao surgimento do Neuromarketing, que pode ser definido como "um campo novo do marketing que estuda a essência do comportamento do consumidor. É a união do marketing com a ciência, considerado uma chave para o entendimento da lógica de consumo, que visa entender os desejos, impulsos e motivações das pessoas através do estudo das reações neurológicas a determinados estímulos externos". (ARIANO, 2013). Ele visa, portanto, trabalhar as emoções das pessoas, através de cheiros e sons, por exemplo, para atingir recordações do passado.

Aqui podemos fazer um paralelo com o que foi explicado no item 2.1.1 sobre a apresentação, atmosfera e ambiente da loja. Vejamos alguns exemplos de como o comércio se utiliza do neuromarketing para fazer o cliente comprar mais: 
- Cores (estímulo visual) - "possuem um efeito significativo em nossas emoções, e a habilidade em usar cores em displays pode motivar-nos a comprar". (DIAMOND, 1999). Cores quentes, por exemplo, são utilizadas para atrair clientes e estimular decisões rápidas; já as cores frias são utilizadas para relaxar os clientes. (CHURCHILL e PETER, 2000).

Figura 3: As ferramentas das Cores
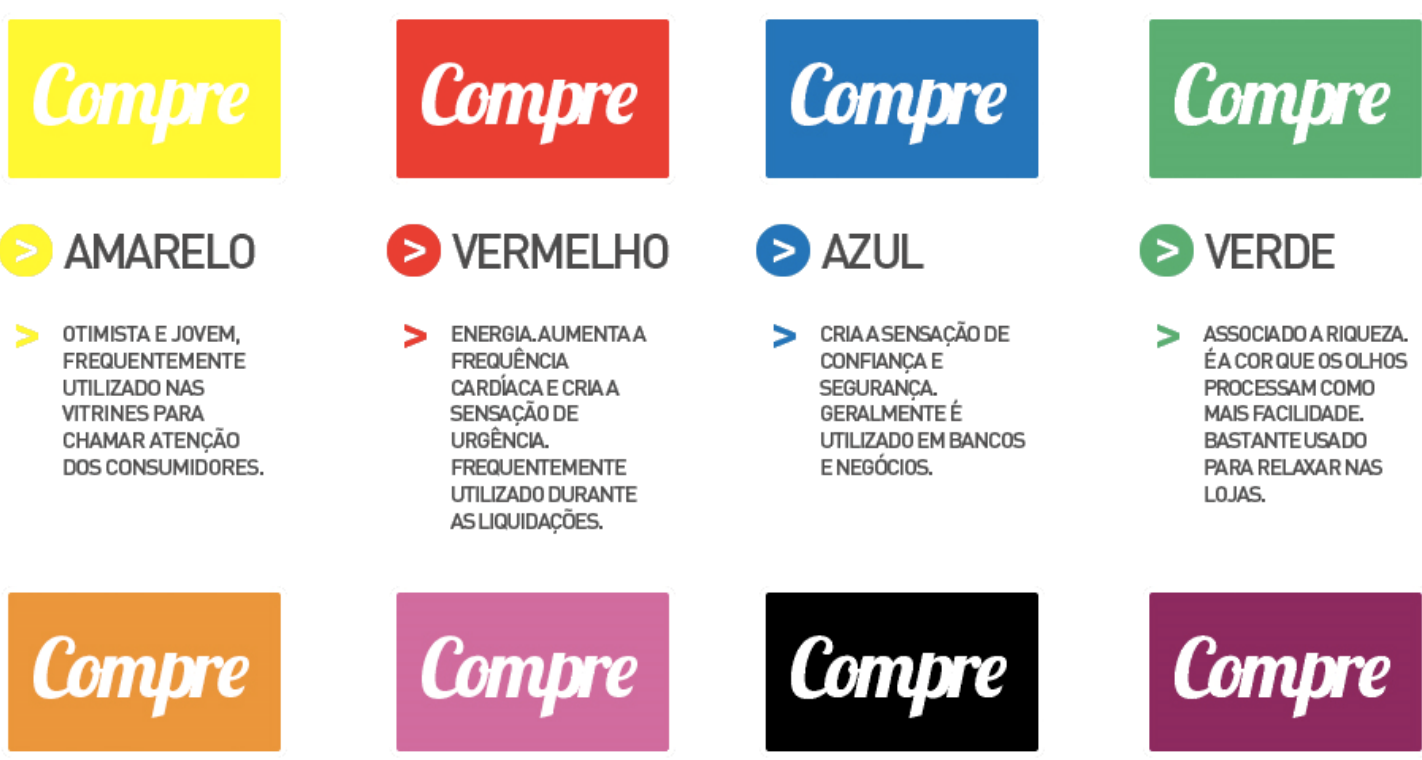

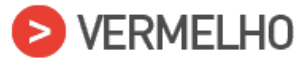
$>$ ENERGIA.AUMENTAA
FREQUENACIA
CARDIACAECRIAA
SENSAÇÃODE
URGÊNCLA.
FREQUENTEMENTE
UTILIZADO DURANTE
ASUIQUIDACÕES.

$>$ AZUL

CRIAASENSAÇÃODE
CONFIANCCAE

SEGURANÇA.

GERALMENTEÉ

UTILZADOEMBANCOS

ENEGÓCIOS.

$>$ VERDE

> ASSOCIADOARIQUEZA. ÉACORQUE OSOLHOS PROCESSAM COMO MAIS FACILIDADE. BASTANTEUSADO PARA RELAXAR NAS LOJAS.
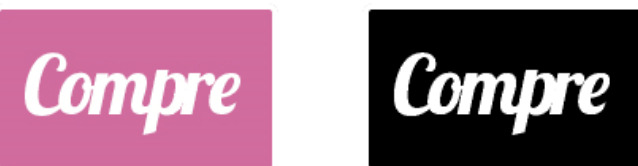

\section{Compre}

\section{$>$ LARANJA \\ AGRESSIVIDADE. CRIA UMA "CHAMADA PARA ACÃO": INSCREVA-SE, COMPREOUVENDA.}

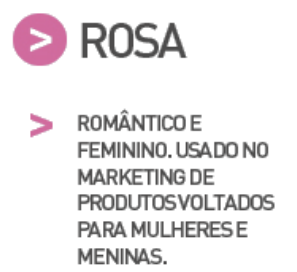

$\gg$ PRETO

$>$ PODEROSOESUAVE.

PRODUTTSDO

MERCADO DELUXO.
$>$ ROXO

$>$ ÉUSADOPARA ACALMAR. GERALMENTEÉVISTO EM PRODUTOSDE BELEZAOU

Fonte: Widrich, 2013

- Iluminação (estímulo visual) - deixar as lojas mais iluminadas reflete mais nas vendas do varejo. Isso porque "a claridade é psicologicamente mais atraente. Uma loja mais clara convida o cliente a permanecer mais tempo, o que é o principal objetivo para a maioria dos varejistas". (PARENTE, 2007). São utilizadas algumas estratégias, tais como dar destaque aos produtos e utilizar uma iluminação diferente em áreas de circulação da loja. 
- Odores e perfumes (estímulo olfativo) - "mexem com as emoções dos consumidores e influenciam na percepção da atmosfera da loja, servindo como reforço positivo. Os aromas influenciam na motivação dos consumidores em relação à loja, pois um aroma pode proporcionar informações adicionais sobre o ambiente, o produto ou a loja". (PARENTE, 2007, p. 298). Por exemplo, "aromas de comida podem despertar o apetite em mercearias ou restaurantes; outros odores podem atrair consumidores para lojas ou produtos. (CHURCHILL e PETER, 2000, p.431). Os aromas, que são intangíveis, podem passar sensações de prazer, qualidade, sofisticação a uma loja ou produto. Muitas vezes os varejistas percebem uma oportunidade de expandir sua linha de produtos ao tangibilizar seu aroma através da venda do mesmo para os consumidores. Os aromas podem fidelizar os clientes; aumentar sua probabilidade permanecer na loja e de comprar e aumentar a qualidade percebida. Segundo uma pesquisa conduzida na Alemanha, aromatizar o ambiente de uma loja aumenta sua probabilidade de venda em até 15\%.

- Apelo ao tato (estímulo tátil) - sentir o produto, poder pegá-lo e experimentá-lo fazem parte do contato físico que os consumidores desejam ter, pois "esse contato físico com o produto produz grande gratificação do consumidor, gera um prazer antecipado à posse do produto e consiste, muitas vezes, em etapa indispensável no processo de decisão de compra”. (PARENTE, 2007, p.298). Deixar os consumidores manusearem um produto exposto em um balcão, como, por exemplo, celulares, Ihes oferece a oportunidade de testar o produto e até imaginálo como seu.

- Som (estímulo auditivo) - existem empresas especializadas em criar uma identidade musical para as lojas do varejo e outros segmentos do mercado, como é o caso da Rádio Ibiza. Eles são responsáveis por customizar trilhas sonoras de acordo com cada marca e com seus segmentos. Isso porque estudos feitos por MILLIMAN (1986) "constatam que a música afeta o processo de compra do consumidor. Música mais rápida torna o processo de compra mais acelerado, enquanto música mais suave torna o ritmo da compra mais devagar. A música lenta estimula o consumidor a permanecer mais tempo na loja, aumentando assim o seu volume de compras." Segundo uma pesquisa conduzida no Reino Unido, a utilização de uma música agradável em uma loja, faz com 
que o cliente passe mais tempo nela, tenha vontade de voltar, e a recomende para outras pessoas.

- Apelo ao paladar (estímulo gustativo) - muitos supermercados utilizam essa estratégia quando oferecem degustações de produtos novos como uma forma de tornar a experiência da compra mais prazerosa. Há lojas de varejo que no lançamento de uma nova coleção ou abertura de um novo ponto de venda convidam clientes para um coquetel e enquanto saboreiam os petiscos aproveitam para conhecer a coleção nova.

Todos esses elementos são trabalhados pelo profissional de visual merchandising baseados no conceito de neuromarketing com a tarefa de captar o consumidor. Uma vitrine bem montada não só atrai a atenção do consumidor como também tem a intenção de fazê-lo voltar à loja. Isso porque é muito mais fácil fazer com que um consumidor que está na loja compre mais, do que atrair um novo consumidor para entrar na loja. (DUNNE e LUSCH, 1999, p. 465)

\subsection{Comportamento do Consumidor}

O propósito do marketing é satisfazer as necessidades e os desejos dos clientes-alvo. Estudar o consumidor ajuda a melhorar ou lançar produtos e serviços, determinar preços, projetar canais, elaborar mensagens e desenvolver outras atividades de marketing. (KOTLER e KELLER, 2006). De nada adianta criar inúmeras estratégias e táticas de marketing se o consumidor não for estudado. É preciso entender quem são esses consumidores, quais as suas motivações, entender que o comportamento do consumidor é um processo contínuo, ou seja, ele ocorre antes da compra, durante a compra e após a compra, não se restringindo apenas ao instante em que o consumidor faz 0 pagamento. Há ainda de se considerar que "à medida que a concorrência aumenta, as empresas, varejistas ou não, procuram aperfeiçoar-se continuamente para satisfazer seus clientes e, assim, conseguir sobreviver, pois o propósito de qualquer empresa deve ser o de conquistar clientes e de mantêlos com alto grau de satisfação". (Parente, 2007, p. 111).

Para Solomon (2011, p.33) o comportamento do consumidor é o estudo dos processos envolvidos quando indivíduos ou grupos selecionam, compram, 
usam ou descartam produtos, serviços, ideias ou experiências para satisfazer necessidades e desejos. Para entendê-lo os profissionais de marketing estudam pensamentos, sentimentos, ações e as influências sobre eles que determinam mudanças. (CHURCHILL E PETER, 2000). Por conta disso, deve-se levar em consideração primeiramente que os consumidores são diferentes, embora exista um modelo de processo de compra pelo qual todos os consumidores passam e que consiste em cinco etapas:

1. Reconhecimento da necessidade

2. Busca de informações

3. Avaliação de alternativas

4. Decisão de compra

5. Avaliação pós-compra

Figura 4: Modelo de Processo de Compra do Consumidor

\section{Modelo de Processo de Compra do Consumidor}

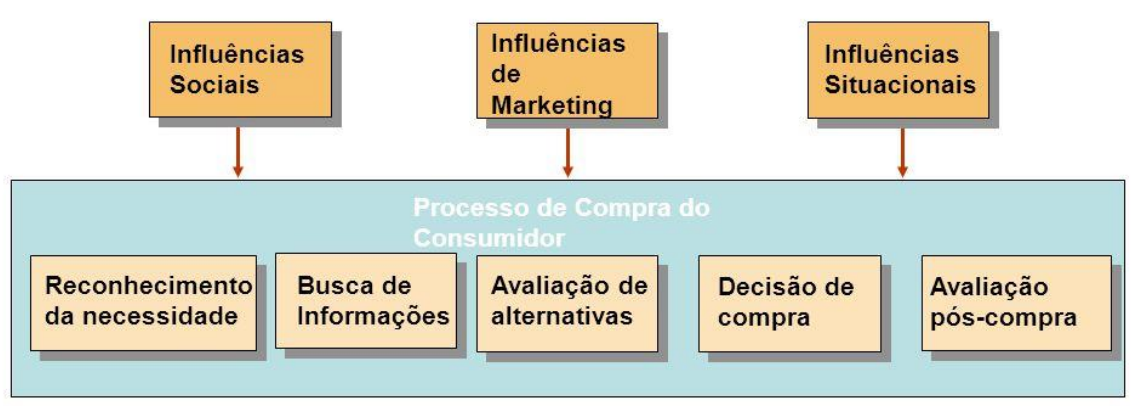

(Fonte: Reis, 2013)

Em todas essas etapas os consumidores sofrem influências sociais, influências de marketing e influências situacionais. Quando se trata de reconhecer uma necessidade, a motivação é fator determinante, pois é um impulso interior que atende as necessidades do ser humano. (CHURCHILL e PETER, 2000). Estas necessidades podem ser utilitárias, ou seja, são necessidades básicas e há ainda as necessidades hedônicas que são necessidades relacionadas ao desejo de prazer e auto-expressão. (CHURCHILL 
e PETER, 2000). Vivemos numa cultura orientada para o consumo, por isso, as pessoas compram não somente o que precisam, mas também compram para satisfazer seus desejos.

Por conta dessas necessidades do consumidor e das influências de marketing, as empresas vêm apostando cada vez mais em estratégias que visam criar lealdade com a sua marca se baseando no consumo hedônico, sendo uma dessas estratégias o marketing olfativo.

Através de pesquisa feita pela consultoria especializada em marketing olfativo La Vie Aromas, foi comprovado que a estratégia de utilização de fragrâncias personalizadas pode aumentar em até $15 \%$ a permanência do consumidor no ponto de venda e o aumento da probabilidade de compra. Já as vendas podem ter um aumento de, em média, $6 \%$. A pesquisa ainda mostra que a utilização da aromatização cria uma fidelização do cliente com a loja, além dessa estratégia ser um diferencial de mercado e que estimula as vendas.

As lojas escolhidas para realizar o estudo são lojas que adotam essa estratégia de marketing olfativo. Essas lojas são conhecidas por possuir um aroma marcante e também comercializam o cheiro para quem desejar tê-lo em casa.

\subsection{O Marketing Olfativo cria uma Identidade Olfativa}

Todos os dias, estamos cercados de inúmeras propagandas visuais ou auditivas, produtos novos e ofertas variadas que visam captar nossa atenção de forma consciente ou inconsciente. As marcas tentam de todas as formas explorar os sentidos das pessoas, mas ainda assim não são todos os nossos sentidos que são alcançados através dessas estratégias. Por conta desse excesso de informações, muitas vezes não prestamos mais atenção em tanta propaganda, pois as pessoas acabam fazendo um filtro diante de tanta coisa que é veiculada. Por isso, apesar de algumas lojas se utilizarem de vitrines bem montadas, iluminação impecável, que dá destaque a seus produtos, preços e até mesmo arquitetura para seduzir os clientes; a nova estratégia adotada, de uns tempos para cá, por inúmeras lojas é seduzir o cliente pelo cheiro. As pessoas podem até se "desligar" das propagandas visuais, mas é muito mais difícil que isso ocorra com o cheiro, uma vez que nosso olfato está funcionando 24 horas por dia e, portanto, mesmo entrando em uma loja e não olhando todos os produtos que ela tem a oferecer, se ela possui um cheiro, é impossível que as 
pessoas não o percebam, pois não deixamos de respirar ao entrar num ambiente.

De acordo com FARKAS (2013, p. 77), "o que se deseja com o marketing é tornar uma marca atraente, desejável, reconhecível, distinta e relevante, objetiva ou subjetivamente, para os seus públicos. Atrair e fidelizar: este é o caminho para vendas saudáveis e negócios sustentáveis". Por isso, a perfumista acredita que o grande poder do marketing olfativo está no fato de lidar com o universo profundo da psique humana.

Já para o Scent Marketing Institute, uma organização americana especializada em marketing sensorial e olfativo, o olfato é o sentido mais forte e principal entre todos os outros. Graças a ele, conseguimos nos proteger, por exemplo, de comer uma comida estragada ou até mesmo ficarmos alerta ao sentirmos um cheiro forte de gás. Além disso, o olfato também nos remete a bons ou maus momentos que vivemos no passado, sendo o sentido que evoca o maior nível de recordações. Isso porque o aroma é processado pelo sistema límbico no nosso cérebro que é responsável pela memória e processos emocionais.

No que tange o marketing, o aroma pode ser altamente efetivo em nos ajudar a distinguir um produto de outro. Ele pode estimular uma memória ou um desejo que influencia uma decisão de compra. Por exemplo, um aroma pode nos relembrar associações agradáveis, como cheiro de "casa", da praia ou até mesmo do campo. Essas associações ajudam as pessoas a criarem um ambiente onde elas se sintam confortáveis, se sintam em "casa". No caso dos consumidores, isso impacta suas decisões em ficar mais em um ambiente e consumir mais.

Por conta disso, as empresas estão utilizando o aroma como parte da estratégia do marketing sensorial para aumentar as experiências dos consumidores num local com seus produtos e serviços. Essas experiências permitem que os consumidores desenvolvam memórias profundas e conexões emocionais com uma marca, promovendo as vendas e sua lealdade.

Baseado nisso, entra em cena uma nova ferramenta de marketing: o marketing olfativo. Com o intuito de criar um diferencial e alavancar as vendas, 
esse conceito que já vem sendo muito utilizado em outros países, como EUA e países da Europa e chegou ao Brasil em meados dos anos 90. Porém, de uns tempos para cá a demanda por esse tipo de técnica aumentou significativamente.

Mas afinal, o que é o marketing olfativo, quais são os seus objetivos e por que investir nessa ferramenta? Por ser um conceito novo no mercado, as definições apresentadas são de especialistas na área, como consultores e perfumistas.

De acordo com a empresa Studio d'essences, o marketing olfativo pode ser definido como "uma técnica sensorial que consiste em transmitir a identidade da marca por meio de uma fragrância exclusiva para que ela, pulverizada no ambiente, cause uma percepção positiva e fixe a essência da sua marca no cliente". Seu principal objetivo é através de odores é conquistar a atenção dos consumidores, atraindo-os para as lojas, além de buscar criar uma fidelização com os mesmos e agregar valor à marca, pois o olfato é capaz de produzir uma memória longa às pessoas. De acordo com FARKAS (2013, p. 43), “o olfato está diretamente ligado às sensações, às emoções e às lembranças, e é por essa razão que podemos recordar momentos marcantes por meio dos aromas". Ou seja, o intuito é atrair os consumidores através do cheiro, criando um vínculo emocional com eles.

Os odores podem incitar emoções ou criar uma sensação de tranquilidade, podendo evocar recordações ou aliviar o estresse. (SOLOMON, 2011). Além disso, os aromas são processados pelo sistema límbico, a parte mais primitiva do cérebro e o lugar imediato onde as emoções imediatas são vivenciadas, por isso algumas reações aos aromas provêm de antigas associações que evocam sensações boas ou más. (SOLOMON, 2011).

Tendo em vista essa nova estratégia, muitas lojas varejistas, além do apelo visual, buscam constantemente proporcionar experiências voltadas para as emoções das pessoas, utilizando-se de fragrâncias que visam criar uma memória olfativa com os clientes, deixando-os à vontade para comprar, criando uma experiência agradável. E não são apenas as lojas de varejo de vestuário que recorrem a essa estratégia. Muitas montadoras de automóveis utilizam dessa técnica ao utilizar aquele famoso "cheiro de carro novo" com seus 
consumidores. Dessa forma, ao sentirem o cheiro da loja os consumidores podem associá-lo à marca, mesmo não tendo contato visual com ela no momento. $\mathrm{O}$ intuito ao perfumar um ambiente é despertador sentimentos. Assim, através do aroma as lojas podem alavancar suas vendas bem como criar um diferencial perante suas concorrentes.

"Aromatizar é traduzir a identidade, é inserir os usuários no universo de significados de uma marca, de um produto ou de uma empresa. É proporcionar uma sensação boa ao cliente, é convidá-lo a um universo imaginário, onírico e virtual, procurando criar uma relação que possa, por fim, ocasionar à sua fidelização" (Farkas, 2013, p. 77 e p.78).

De acordo com Farkas (2013), a utilização do marketing olfativo desempenha algumas funções, entre elas:

- Identificar a marca, distinguindo-as das outras.

- Aumentar fortemente o apelo de vendas no ponto de vendas ou diminuir a rejeição a produtos.

- Gerar sensações que melhoram as relações humanas no ambiente de trabalho.

- Ajudar a regular emocionalmente as relações entre o cliente e o negócio, particularmente no varejo, em que se pode, por exemplo, aumentar ou diminuir o desejo de permanência do cliente no espaço de vendas e outros efeitos.

- Transmitir ao cliente um cuidado especial com ele durante a sua permanência no espaço de interação.

Baseado nisso, muitas marcas perceberam a oportunidade de explorar 0 olfato das pessoas e junto à empresas especializadas em marketing olfativo, desenvolveram uma identidade olfativa para elas. Dessa forma, conseguem estabelecer, através de um aroma, um vínculo com seus consumidores.

\subsubsection{Identidade Olfativa}

O cheiro tem um papel importante na identificação de uma marca ou produto. Quem já não entrou em uma loja que tem um cheiro característico e que depois foi capaz de reconhecer? A escolha de uma fragrância como identidade olfativa de uma loja deverá sempre levar em conta a criação de um ambiente 
agradável para quem a está visitando, ou seja, fazer com que a loja ofereça uma experiência prazerosa para o cliente.

A empresa JING, que realiza projetos de Marketing Olfativo, define Identidade Olfativa como "o design olfativo da fusão de traços naturais, qualidades particulares e propriedades originais que distingue uma marca da outra". Ainda segundo a Jing, "criar uma fragrância exclusiva associada a uma marca é dar a ela uma Identidade Olfativa".

Segundo Fábio Sacheto, da empresa Florus, Cosméticos sob Medida, "o principal ponto da Identidade Olfativa é produzir sensações: despertar desejos, reavivar memórias, provocar sentidos, surpreender, estabelecer uma relação emocional, criar um ambiente memorável, único, diferente e inesquecível".

Para se criar uma Identidade Olfativa para uma loja, por exemplo, seria necessário, primeiramente, levar em conta 4 fatores: a filosofia da marca (missão/proposta do produto), o layout da loja (decoração, design, arquitetura), o ambiente da loja (externo e interno) e o público alvo (feminino, masculino, adolescente, etc.), para depois se definir o que se quer transmitir: sofisticação, descontração ou beleza, por exemplo

\subsubsection{Desenvolvimento da Identidade Olfativa}

Escolher um aroma que identifique uma marca ou produto e que desperte algum tipo de sensação agradável nos clientes é uma tarefa que exigirá um trabalho minucioso da empresa aromatizadora. Isso ocorre, pois de acordo com Fernando Amaral, sócio da empresa Aromagia, especializada no desenvolvimento de fragrâncias, "a comunicação olfativa deve ser personalizada e só cumpre o seu papel quando evoca a lembrança de determinada marca ou lugar. Aromas clássicos, disponíveis para todo o mercado, não surtem efeito porque estão veiculados a outras referências e podem confundir o consumidor, que não saberá exatamente onde e quando sentiu aquele cheiro". Por isso, para que se chegue a um bom resultado, deve-se primeiramente fazer uma análise da faixa etária e hábitos do cliente, e cruzar esses dados com a filosofia da marca ou do produto, levando em consideração alguns aspectos, como: de que forma o cheiro agradará o cliente? Será que ele sentirá prazer? Terá mais vontade de permanecer na loja? O cheiro trará recordações? Outro aspecto importante é a 
quantidade de fragrância que deve ser lançada, por meio de difusão, ventilação, nebulização ou outra técnica utilizada pela empresa de aromatização.

A empresa CROMA, por exemplo, que é especializada na elaboração de logos olfativos, realiza as seguintes etapas junto a seus clientes:

- Encaminha para o cliente um briefing com algumas perguntas que dirigirão a criação das fragrâncias.

- Solicita junto a seus fornecedores matérias-primas e novidades com base nas respostas do cliente.

- Cria fragrâncias que assegurem a originalidade da identidade olfativa.

- Apresenta 6 fragrâncias em forma de refis.

- Envia um mini- difusor para o cliente testar as fragrâncias. O mini-difusor será ligado em uma sala de reuniões. Pessoas serão convidadas a dar sua opinião sobre as fragrâncias e preencher um questionário fornecido pela empresa.

- Após a escolha da fragrância, uma descrição olfativa será encaminhada ao cliente de todas as notas de topo, meio e fundo, e a explicação do porque de sua escolha para que seja utilizada pelo marketing.

\subsection{Aromaterapia}

Para a especialista em aromaterapia Shirley Price a "aromaterapia é a utilização controlada e consciente dos óleos essenciais das plantas, com o objetivo de prover saúde e bem estar à totalidade do indivíduo, isto é, ao conjunto formado por corpo, mente e espírito".

Sendo assim, a aromaterapia é uma ferramenta fundamental para o marketing olfativo. Isto porque existem inúmeros tipos de aromas e para a seleção dos mesmos deve-se levar em consideração o tipo de público da loja, o produto que ela vende, o local onde ela se encontra e até mesmo sua decoração. Quando uma empresa especializada em marketing olfativo é contatada, é feito um briefing com o contratante para que eles consigam, dentre a extensa variedade de aromas existentes, chegar a um cheiro que seja a cara da loja a fim de Ihe conferir uma identidade olfativa. Normalmente, o especialista em aromatização combina uma ou mais fragrâncias, o que é conhecido como sinergia. Essa sinergia é necessária, pois de acordo com a perfumista Fátima 
Leão Farkas, a combinação de dois ou mais óleos essenciais pode amplificar o odor e obter um melhor resultado aromático. Mas afinal, o que é aroma e qual seu papel?

De acordo com FARKAS (2013, p. 19), "podemos chamar de aroma a sensação desencadeada no nosso sistema olfativo na presença de um complexo de substâncias odoríferas que, ao serem percebidas pelo nosso organismo, desencadeiam sensações - prazer e desagrado, entre outras. Ele tem poder de repelir ou atrair, de fazer a pessoa permanecer menos ou mais tempo em um ambiente". A perfumista ainda divide os aromas em duas categorias:

- Naturais - encontrados diretamente na natureza

- Artificiais - produzidos em laboratório

Portanto, os aromas têm um papel cada vez mais importante na percepção de uma marca, na construção de sua identidade e na fidelização dos seus clientes. (FARKAS, 2013).

De acordo com estudos feitos por empresas especializadas em marketing olfativo, tais como a Aromatize e Biomist, existem aromas que fazem com que mesmo que o cheiro da loja não seja o preferido da pessoa, se ele for agradável já é suficiente para que o consumidor permaneça mais tempo nas lojas.

\subsection{O mercado da indústria do "cheiro" no Brasil}

Na década de 1970, a aromatização ambiental já era utilizada nos cassinos de Las Vegas, Estados Unidos, para manter os apostadores jogando por mais tempo. No Brasil, o uso da aromatização ambiental só foi iniciado em meados dos anos 90 por alguns supermercados que visavam atrair a atenção dos clientes para um produto em oferta ou para uma área onde poucos clientes transitavam. No entanto, foi nos anos 2000 que o marketing olfativo teve impacto no país. Hoje, não só marcas famosas, mas também pequenos comércios utilizam este recurso, que vem sendo adotado também por empresas dos mais variados setores no Brasil, como restaurantes, bancos, hospitais, hotéis, escritórios, bancos, shoppings e até mesmo academias. Todos eles visam criar sua identidade olfativa melhorando a experiência do consumidor com seu produto ou serviço. Por exemplo, o ambiente bancário normalmente envolve 
muita tensão e estresse, por isso são utilizados aromas que diminuam a ansiedade do cliente. Já no caso dos hotéis, a proposta é fazer com que o hóspede se sinta em um ambiente familiar desde o momento em que realiza o check-in até o momento do check-out. São utilizados, então, aromas que suaves nos corredores para criar essa atmosfera mais confortável. No varejo não poderia ser diferente. Por isso, visando que os consumidores tenham uma boa experiência com a loja, determinando seu retorno à ela, os varejistas apostam na utilização de aromas que mexam com o emocional das pessoas, incentivando a compra por impulso, tornando a marca reconhecida e inesquecível.

Segundo Olavo Falleiros, presidente da MIB - especializada em soluções para o mercado promocional, "no Brasil, estamos vendo cada dia mais lojas de moda que se equipam de uma fragrância como identidade olfativa. Faz cada vez mais parte dos valores e do DNA das marcas. Hoje, é comum passear em um shopping e já nos corredores sentir varias fragrâncias. A tendência é usar cada vez mais esse recurso para satisfazer o cliente e marcar mais, na mente dele, uma identificação olfativa".

Gustavo Carrer, consultor de marketing do SEBRAE-SP diz que "no Brasil já se pratica o marketing sensorial há alguns anos, mas apenas mais recentemente, os empreendedores brasileiros se deram conta da influência que esse tipo de ação pode exercer no consumo e, consequentemente, refletir de maneira positiva no faturamento da empresa".

Resumidamente, quais são, então, alguns dos motivos para se utilizar o Marketing Olfativo em lojas do varejo?

- Estabelecer um vínculo com o cliente, pois quando este estiver longe do ponto de venda, certamente lembrará da marca, o que pode influenciar em sua decisão de compra.

- Estimular a curiosidade dos clientes que estiverem no entorno do estabelecimento, ampliando sua motivação para visitá-lo. 
- Fortalecer a relação cliente x marca, o que possivelmente resultará na fidelização do cliente, em sua indicação do estabelecimento para sua rede de contatos, e no consequente crescimento das vendas.

- Aumentar as vendas entre $5 \%$ e $50 \%$, de acordo com pesquisas.

- Melhorar o posicionamento da marca e a experiência do consumidor com ela, através da associação da marca com um aroma específico.

- Garantir, através de um aroma agradável, que os consumidores queiram permanecer mais tempo no ambiente e prefiram voltar mais rapidamente à loja, criando assim uma atmosfera ideal.

- Influenciar a percepção de qualidade dos produtos ou serviços pelos consumidores através da utilização de um aroma.

Dentre as diversas empresas de aromatização ambiental no Brasil, destacamos algumas, para fins ilustrativos:

Aromatize Marketing Olfativo - Iniciou sua operação em 2010, sendo distribuidora de grande organização especializada em marketing olfativo, adquirindo assim Know-how mundial em fragrâncias introduzindo a ferramenta sensorial em diversos segmentos no mercado nacional.

Aromatizar - empresa de marketing olfativo e distribuidora exclusiva no Brasil da marca Air/Q, líder no mercado mundial de aromatização profissional de ambientes, com grandes clientes como Abercrombie \& Fitch, Armani, Hyundai, Mercedes-Benz, entre outros.

Airomas Aromatização Profissional de Ambientes - Desde sua instalação no Brasil no ano de 2010, a AIROMAS se converteu rapidamente na empresa líder em aplicação de aromas e fragrâncias no ambiente para influir nas percepções, nos gostos, nos estados de ânimo e nas apetências das pessoas. 
Avatim Cheiros da Terra - Pioneira no mercado de aromatizantes, a Avatim busca na biodiversidade da Mata Atlântica o estímulo e recursos necessários para a criação de um grande leque de fragrâncias e produtos voltados para o bem-estar.

Biomist Marketing Olfativo - Há 14 anos a Biomist pratica consultoria na aplicação de Marketing Olfativo, desenvolvimento de fragrâncias bem como prestação de serviços para aplicação desta através da aromatização de ambientes e confecção de produtos. Alguns de seus clientes são: Zara Home, Nike, Kopenhagen e Vila Romana.

Básico Aroma - nasceu no ano de 1999, com o propósito de atender a crescente demanda do mercado por produtos que proporcionasse bem-estar dentro de empresas e residências.

Cheiro Bom - Líder de mercado em aromatização de ambientes e pioneira na introdução do conceito de Marketing Olfativo no Brasil. Desenvolve fragrâncias exclusivas e instalamos os equipamentos em comodato.

Croma - empresa brasileira especializada em elaborar identidade olfativa de marcas, atuando na área de aromatização ambiental. Sua carteira de clientes possui alguns nomes bastante conhecidos no mercado, como as empresas $O$ Boticário, Unilever, Fiat, Grendene e Natura.

Camaleão Olfative Marketing - fundada pela perfumista Fátima Leão Farkas, a empresa é mais uma especializada em aromatizar ambientes e já fez trabalhos para clientes importantes, como: Tok Stok, Hotel Grand Hyatt São Paulo, Daslu, Eletrolux, entre outros.

Jing - empresa que também realiza projetos de marketing olfativo e que atua há mais de 10 anos no mercado. Entre seus principais clientes estão: Cantão, Farm, Taco e Via Mia. 


\subsubsection{A estratégia da venda pelo "cheiro"}

Quando uma empresa especializada em marketing olfativo é procurada por uma loja de qualquer segmento do varejo, deve-se primeiramente levar em consideração dois questionamentos: Quais seriam os benefícios obtidos através do uso da estratégia de aromatização? A aromatização fará com que os clientes comprem mais o produto da loja? De acordo com um artigo publicado pela empresa Biomist não é possível afirmar categoricamente se os clientes comprarão mais somente por conta do cheiro, pois há outras variáveis que devem ser levadas em conta ao se consumir, como por exemplo, o preço dos produtos e se há algum tipo de promoção na loja. Portanto, mensurar as vendas por conta do aroma é uma tarefa intangível. Porém, uma pesquisa conduzida na Alemanha demonstrou que o uso de aromas personalizados aumenta o tempo que o cliente fica na loja em 15,9\%, e a probabilidade de que ele compre na loja em 14,8\%. Porém o Point of Purchase Advertising International - Popai, uma organização americana, sem fins lucrativos, que promove 0 valor do merchandising no ponto de venda de varejistas, divulgou que a estratégia de marketing olfativo contribui para aumentar o faturamento do varejo em torno de $20 \%$.

De qualquer modo, ao se aromatizar um ambiente cria-se uma atmosfera favorável que estimula o bem-estar do consumidor. Quando há uma harmonia entre o aroma da loja e os demais aspectos que compõe sua atmosfera, a experiência de compra do consumidor é melhor e a chance dele ter uma lembrança agradável é maior.

Muitas marcas percebem o potencial do aroma de suas lojas ou produtos e apostam na comercialização do mesmo para os consumidores. É o caso dos perfumes da Ferrari, como explica a coordenadora de Marketing da empresa Airsense, Mônica Callis: "a pessoa pode não ter o poder aquisitivo para adquirir um automóvel da marca, mas adquirir o perfume já remete a uma sensação de status e poder". Outro exemplo é o caso da rede de lingerie Any Any, que vende não só a colônia como o difusor de aroma e creme hidratante com o cheiro da loja. A venda da fragrância da loja já corresponde a $10 \%$ do total de vendas, provando que o consumidor quer ter em casa aquele cheiro que the traz sensação de um ambiente aconchegante, fazendo com que ao chegar a casa ele ainda tenha uma experiência com a loja. 
Um dado interessante diz respeito a como os brasileiros têm o hábito de usar muito perfume, tendo o Brasil se tornado "o maior mercado consumidor de perfumaria do mundo", segundo Isabela Massola, gerente de marketing de desenvolvimento de produtos da Natura. Podemos inferir, portanto, que se o "cheiro" tem um papel relevante na vida dos brasileiros, o mercado de aromatização concentrará sua atenção nas famílias olfativas que mais agradam os consumidores brasileiros. Segundo o perfumista Thierry Bessard, "o caminho para se tornar um "nariz" (nome como são conhecidos os perfumistas dentro de seu próprio meio) começa pelo aprendizado da identificação das grandes famílias olfativas." Segundo pesquisa, as mulheres brasileiras preferem os aromas florais e o homens preferem as fragrâncias amadeiradas. Hinayana Silva, design da FUCAPI (Fundação Centro de Análise, Pesquisa e Inovação Tecnológica) diz que "no Brasil, se uma marca aplicasse aroma de pinho em uma peça de vestuário provavelmente não haveria aceitação, em função deste cheiro estar associado a detergentes".

As quatro lojas escolhidas para o estudo possuem aromas próprios e são comercializados para o público.

\section{FARM}

Figura 5: Aromatizador Farm

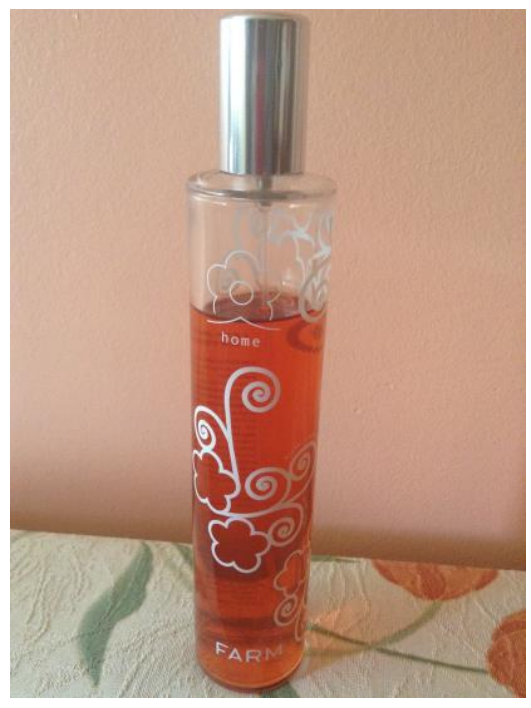

Fonte: Arquivo pessoal 
A história da FARM começou em 1997 na Babilônia Feira Hype. Os sócios Kátia Barros e Marcello Bastos participaram do evento e o stand da Farm foi o mais badalado, batendo recorde de vendas. Decidiram, em 1999, abrir uma loja em Copacabana e nos anos seguintes o sucesso era tanto que a marca foi se expandindo para outros bairros da cidade carioca.

O estilo da FARM é voltado para meninas despojadas, com tendência hippie-romântica, e a maioria delas jovens. A loja também comercializa o seu "cheirinho" e é sucesso absoluto entre as clientes. Para o gerente de Branding da Farm, Carlos Mach, "o cheiro da FARM está na memória de todos que amam a marca".

\section{MARIA FILÓ}

Figura 6: Aromatizador Maria Filó

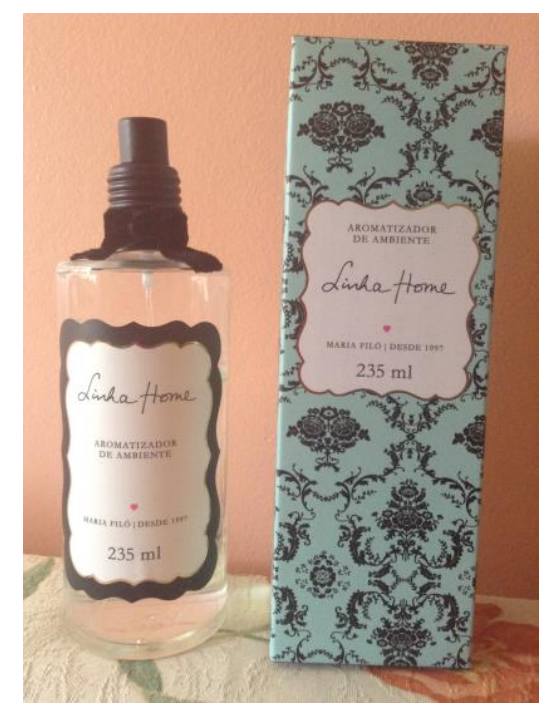

Fonte: Arquivo pessoal

Criada no Rio de Janeiro, em 1997, a Maria Filó é uma loja voltada exclusivamente para o público feminino e se inspira nas mulheres que se expressam através da sua feminilidade. Por isso, a loja de desenvolveu uma fragrância que reproduz o romantismo e, claro, a feminilidade de suas coleções. Atualmente comercializa seu aromatizador para suas clientes, além de ter investido também na criação de um sabonete líquido com o cheirinho da loja. 


\section{LE LIS BLANC}

Figura 7: Aromatizador Le Lis Blanc

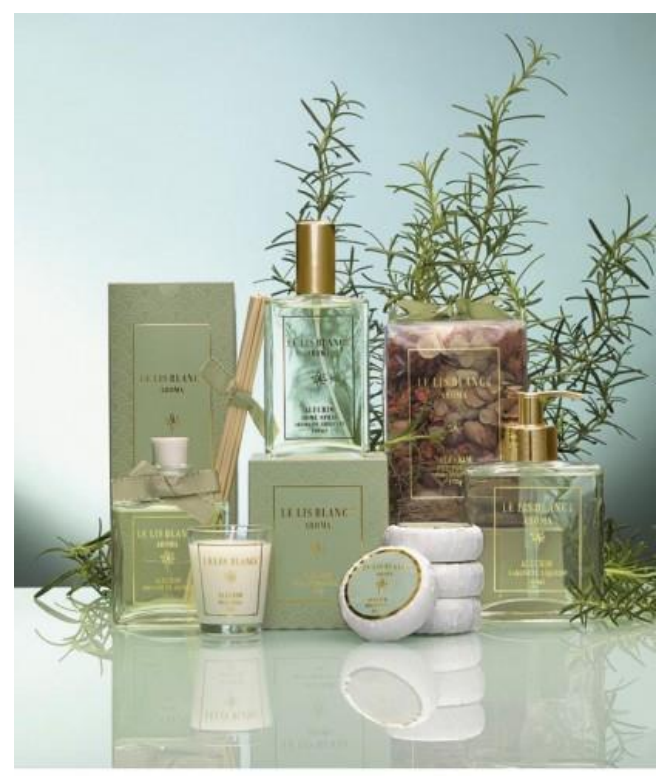

Fonte: Site Le Lis Blanc

Fundada em 1988, a Le Lis Blanc é uma loja cujo público-alvo é voltado para mulheres com alto poder aquisitivo, de diferentes faixas etárias, que procurem produtos elegantes e femininos, inspirados em tendências internacionais.

Além das suas luxuosas coleções, a grife diversificou seu portfolio, expandindo sua linha de produtos. Em 2005, criou a linha "Le Lis Blanc Casa", onde é possível encontrar diversos itens para o lar, como almofadas, móveis, artigos de cama, lustres, etc. Em 2009 criou a linha "Le Lis Petit" voltada para o público infantil, normalmente as filhas das consumidoras. Percebendo que as grandes grifes internacionais possuem um perfume exclusivo para seus ambientes, a marca criou a linha "Le Lis Aroma" e que virou a sua marca registrada.

A responsável pelo desenvolvimento de produtos da marca, Alessandra Aliperti, afirma que a escolha do aroma, foi pensando em "algo refrescante, que combinasse com nosso clima tropical".

O cheiro de Alecrim que circula pelas lojas é inconfundível e pode ser encontrado em todas as lojas da grife, em forma de sabonetes, aromatizadores de ambiente, difusores e velas. 
Por conta dos preços das peças serem elevados, há relatos de mulheres que já que não têm poder aquisitivo para comprar as roupas, têm pelo menos como comprar o aroma da loja.

\section{CANTÃO}

Figura 8: Aromatizador Cantão

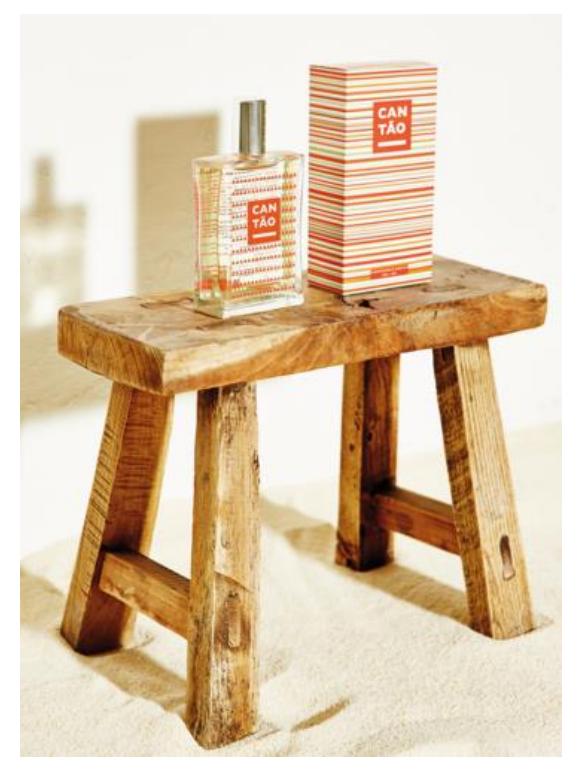

Fonte: Site Cantão

Criada em 1967, no Rio de Janeiro, a Cantão é uma marca que preza pelo bem estar de suas clientes, através de suas roupas com conforto e casuais. A marca valoriza um estilo de vida descontraído que seja capaz de celebrar a mulher autêntica, que transborda emoção e feminilidade.

Por isso, criou uma fragrância que combine com o estilo de suas clientes e hoje é comercializado em todos os seus pontos de venda. O cheiro é tão popular que chega a esgotar nas lojas.

\subsection{Cases de Sucesso}

A fim de ilustrar um pouco mais o trabalho fez-se uma pesquisa sobre dois casos de sucesso envolvendo empresas que investiram no marketing olfativo. 


\section{- Caso Dunkin Donuts}

A empresa americana Dunkin'Donuts, famosa por vender rosquinhas (donuts) e café em vários lugares do mundo, queria mudar sua imagem de apenas ser lembrada como a empresa do donuts e resolveu adotar uma estratégia inusitada para fazer frente com a Starbucks, empresa mais pensada quando se fala em café.

Para realizar seu experimento, a Dunkin'Donuts escolheu Seul, a capital da Coréia do Sul, conhecida por ser a "cidade do café". A indústria do café ainda está crescendo e a competição entre as cafeterias está se tornando ainda mais intensa. A cidade possui aproximadamente 200 unidades da Starbucks, além de outras redes locais de cafeterias.

A Dunkin'Donuts que projeta uma imagem de ser muito mais um local apenas de rosquinhas do que de café decidiu que era hora de adotar uma nova estratégia. A missão da campanha era encorajar as pessoas a escolher pedir café no Dunkin'Donuts ao invés dos concorrentes.

Aproveitando o fato de que além do trânsito na cidade ser caótico, fazendo com que muitas pessoas utilizem o transporte público para ir ao trabalho, como ônibus e metrô, muitas pessoas passam em cafeterias antes de ir para o trabalho. A Dunkin'Donuts começou a pensar em como abordar essas pessoas. Foi aí que surgiu a ideia de lançar o aroma de café juntamente com as propagandas de rádio, criando a ação conhecida como "Flavor Radio". Após a análise do jingle da marca, foi criado um vaporizador que lança o aroma de café da empresa sempre que o anúncio da marca tocava no rádio.

As pessoas que notaram o aroma enquanto escutavam o anúncio apresentaram reações de surpresa. Quando elas saltavam do ônibus e viam uma Dunkin'Donuts iam automaticamente para lá.

Os resultados foram super positivos para a empresa. Mais de 350 mil pessoas foram atingidas por essa ação, aumentando em $16 \%$ o número de visitantes nas lojas próximas as estações de ônibus. As vendas de café tiveram um aumento de $29 \%$ e o resultado da ação foi atingido: agora a Dunkin'Donuts é um local que as pessoas pensam quando querem comprar seu café da manhã.

A ação "Flavor Radio" ainda foi premiada com um Leão de Bronze no festival de Cannes, em 2012. 


\section{- Case Abercrombie \& Fitch}

A Abercrombie \& Fitch é uma loja de varejo cujo público-alvo é voltado para os jovens e é conhecida por utilizar bastante os recursos do marketing sensorial. Seu ambiente mais parece com que a pessoa está indo para uma "balada", devido à sua iluminação e suas músicas. Até abril desse ano, os vendedores, que eram chamados de "modelos" da loja recepcionavam os clientes sem camisa, mas após um conjunto de mudanças na sua política, a empresa resolveu que os antigos "modelos" agora poderão utilizar camisa e são chamados de "representantes da marca". No que tange o marketing olfativo, a empresa investe pesadamente no aroma. O cheiro da loja pode ser reconhecido de longe e o sucesso é tanto que foi lançado um perfume, chamado "Fierce" da marca, que é vendido não apenas como um cheiro, mas como um estilo de vida. Ele é definido como um cheiro elegante, sensual e sofisticado. O sucesso do perfume é tanto que desde que a empresa começou a comercializá-lo, em 2008, ela já lucrou mais de 250 milhões de dólares.

\subsection{Curiosidades}

Nesta seção são abordadas três casos curiosos, retirados do blog da empresa Biomist, que envolvem o marketing olfativo e que ajudam a ilustrar e enriquecer o presente trabalho.

A maioria das montadoras de carro, como Audi, Ford e Volkswagen possui um time especialista em cheiro, conhecidos como "nose team" (time dos narizes)? De acordo com a supervisora de acabamento da Ford, Adília da Conceição Afonso, "o cheiro está associado à conquista do carro novo". Por isso, essa equipe é responsável por cheirar peça por peça do veículo, em clínicas, e atribuir uma nota que varia de uma escala de 1 (inodoro) a 6 (insuportável). Caso os cheiros não agradem aos especialistas ou causem alergias, eles são reformulados. O "nose team" da Audi já existe desde 1985 e é composto por 4 mulheres e 2 homens. O chefe de laboratório de odores da marca, Heiko Lüssmann-Geiger afirma: "não adicionamos aromatizantes aos componentes. Apenas fazemos a combinação correta deles na cabine. Cada modelo possui um aroma para atrair o seu público". 
"Você sabia que os produtos da Apple contêm um cheiro específico para que deficientes visuais consigam notar que o produto que estão tocando e/ou segurando é um produto da empresa? A Apple também trabalha o sentido do olfato como parte de sua estratégia de Branding." (Portal Administração). Além disso, de acordo com um artigo publicado pela Biomist, a Air Aroma, empresa americana especializada em marketing olfativo, também desenvolveu um perfume inspirado no cheiro dos produtos novos da Apple, como o computador MacBook Pro. O projeto é conhecido como "Stink Diffrent" que faz alusão ao slogan da Apple "Think Different". A ideia da empresa é "refazer a sensação que a pessoa tem ao abrir a caixa do notebook da Apple". No entanto, a fragrância não foi criada com vistas a ser comercializada para os "Apple maníacos", mas sim ser utilizada em uma exposição.

O Boticário, em 2009, resolveu inovar e lançou o primeiro cartão de crédito perfumado do mundo, em parceria com o banco Bradesco. Ao passar o cartão na maquininha ou esfrega-lo com as mãos, o atrito libera um odor com cheiro de rosas e jasmim, como explica a reportagem de Clara Vieira da revista EXAME (2009). O intuito dessa iniciativa é aumentar a sensação de bem-estar das mulheres após as compras. Além disso, o cartão é obviamente um produto diferenciado, pois une a vantagem do crédito com o programa de fidelidade da empresa, fazendo que as consumidoras possam trocar seus pontos por produtos da marca; ganhem "cupom" de desconto de até $20 \%$ em qualquer loja do Boticário; possam parcelar as compras em até 10x e acumular milhas em companhias aéreas. A diretora de Marketing e Vendas do Boticário, Andréa Mota, explica: "Identificamos a necessidade de consumidores que desejam adquirir produtos de beleza, mas que não têm acesso ao crédito para facilitar suas compras. Para atendê-los, oferecemos um cartão com as vantagens de que necessitam e com um suave perfume, característica marcante do Boticário. Elegemos o Bradesco como parceiro porque é uma instituição financeira que agrega credibilidade e solidez à marca", completa. O resultado dessa iniciativa foi tão positivo que na época as vendas do cartão aromatizado cresceram $20 \%$. 


\section{Metodologia}

\subsection{Tipo de Pesquisa}

\subsubsection{Quanto aos Fins}

Foi realizada uma pesquisa exploratória, que, segundo Zikmund (2006, p.105) "pode ser conduzida para diagnosticar uma situação, selecionar novas alternativas ou descobrir novas ideias", através de entrevistas com gerente das lojas e um teste cego com potenciais consumidores, pois o intuito foi o de avaliar a estratégia de marketing olfativo das lojas e de que forma seu cheiro impacta os consumidores.

\subsubsection{Quantos aos Meios}

Quanto aos meios, a pesquisa é bibliográfica, por utilizar, paralelamente, materiais como livros, artigos e outros estudos feitos sobre o assunto. E também houve uma pesquisa de campo, cujo objetivo foi coletar informações diretamente com quem possa responder o problema da pesquisa.

\subsection{Universo e Amostra}

O universo da pesquisa é constituído por mulheres brasileiras de idade igual ou maior que 18 anos e residentes do Rio de Janeiro. A amostra pode ser classificada como não probabilística por acessibilidade, e composta por 108 pessoas. 


\subsection{Seleção dos sujeitos}

Os sujeitos selecionados para responder à pesquisa são mulheres que residem no estado do Rio de Janeiro, de idade maior ou igual a 18 anos e potenciais consumidoras das lojas escolhidas para o estudo.

\subsection{Coleta de Dados}

Como foi escolhido o método da pesquisa de campo, a princípio a coleta de dados foi feita através de conversas informais com 8 gerentes das lojas escolhidas. Essas conversas serviram de base como um primeiro contato com o tema e também para elaboração do questionário que foi aplicado junto ao teste cego.

O teste cego foi realizado, em sua maioria, no campus da PUC, visto à facilidade de conseguir respondentes, e também em ambientes perto dos shoppings Rio Sul e shopping Leblon, uma vez que todas as lojas estudadas estão presentes nesses ambientes.

A $1^{\text {a }}$ parte do teste cego consistia nas pessoas responderem 3 questões, que serviam apenas como forma de introduzir o conteúdo restante da pesquisa. Em seguida, um aroma de cada vez foi borrifado em fitas olfativas e foi pedido que as respondentes cheirassem o aroma, marcando a qual loja elas achavam que correspondia aquele cheiro. Com o intuito de não fazer confusão entre os cheiros e enviesar o resultado da pesquisa, foi pedido que as entrevistadas cheirassem um pouco de café para "limpar" seu olfato e conseguir dar prosseguimento ao teste.
A ordem correta dos cheiros era:
Cheiro 1 - FARM
Cheiro 2 - LE LIS BLANC
Cheiro 3 - CANTÃO
Cheiro 4 - MARIA FILÓ

Feito isto, foi pedido que as entrevistadas respondessem a $3^{\text {a }}$ parte do teste que continham perguntas relacionadas aos aromas sentidos e suas percepções a respeito deles e da estratégia do marketing olfativo. 
Figura 9: Aromas para teste cego

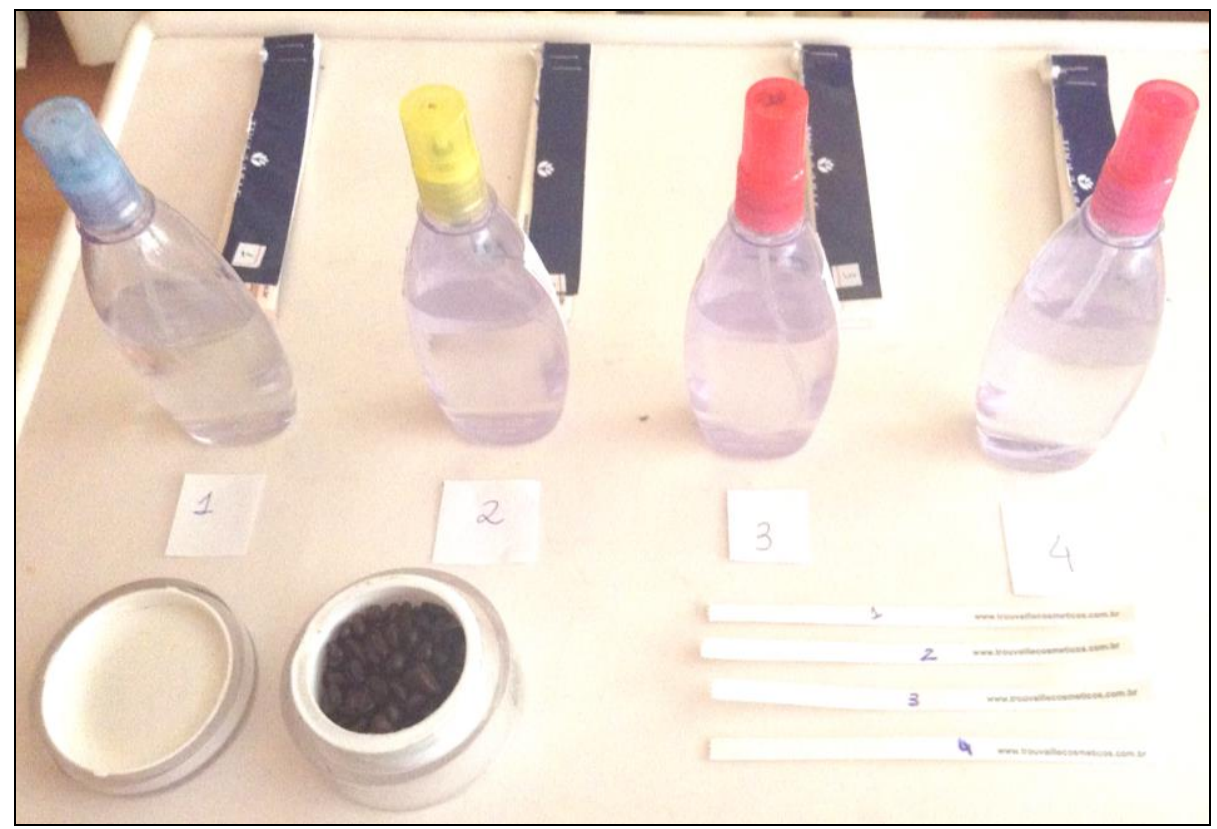

Fonte: Arquivo Pessoal

\subsection{Tratamento dos dados}

Os dados coletados na pesquisa de campo e nas entrevistas foram tratados tanto de forma quantitativa, ou seja, utilizando métodos estatísticos e análises cruzadas de forma a se estabelecer uma correlação entre as respostas fornecidas pelas respondentes.

\subsection{Limitações do método}

O método pode apresentar limitações como falta de tempo e vontade das pessoas em querer responder o questionário ou a dar informações precisas nas entrevistas. Normalmente muitas pessoas se recusam em responder questionários e a participar de testes por não terem vontade de responder, alegando falta de tempo para isso, pois estão sempre com pressa. Além disso, a preferência prévia por alguma marca pode causar viés nos resultados também. 


\section{Apresentação e análise dos resultados}

Este capítulo, dividido em duas seções, apresenta e analisa os resultados obtidos a partir do questionário (Anexo I) aplicado juntamente ao teste cego, de forma a produzir sugestões sobre o estudo. Na primeira seção serão analisados todos os resultados do questionário e na segunda seção serão analisados os resultados obtidos através do cruzamento de alguns dados considerados relevantes.

\subsection{Descrição dos resultados}

A pesquisa teve uma amostra de 108 respondentes, todas mulheres residentes do estado do Rio de Janeiro e o questionário, que contou com 12 perguntas, foi aplicado juntamente com o teste cego.

\subsubsection{Lojas com "cheiros" marcantes}

Na primeira pergunta do questionário foram oferecidas 8 opções de lojas, todas de varejo de vestuário, e que possuem aroma próprio. Buscou-se investigar qual (is) era $(\mathrm{m})$ a(s) loja(s) que mais estava $(\mathrm{m})$ "na cabeça" dos respondentes quando eles pensavam no "cheiro da loja". O intuito dessa pergunta foi tentar despertar a memória olfativa dos respondentes. 


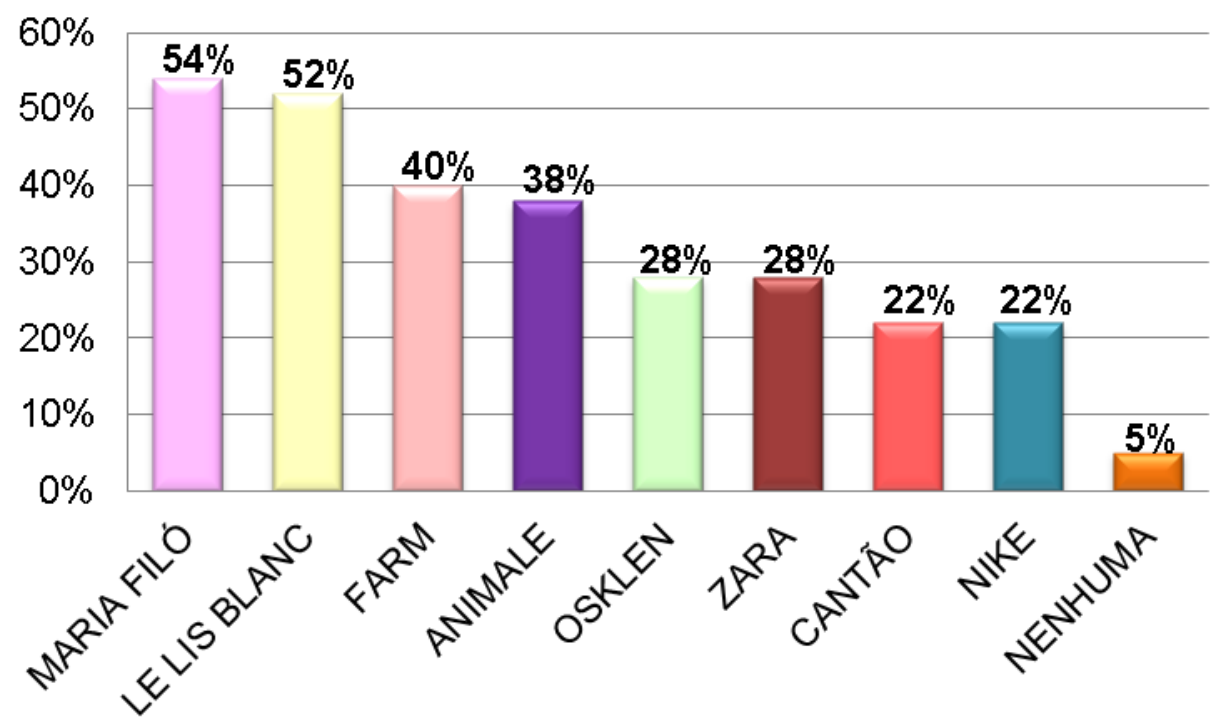

Gráfico 2: Resultado referente à "Q1: Quando você pensa no "cheiro das lojas" alguma das marcas abaixo the vêm à cabeça?"

As marcas Maria Filó e Le Lis Blanc foram as mais lembradas pelos respondentes, representando 54\% e 52\%, respectivamente, dos resultados. Em seguida, com 40\% aparece a marca Farm, na 3a posição. A marca Animale ocupou a $4^{\circ}$ posição sendo lembrada por $38 \%$ dos respondentes. Com $28 \%$ as marcas Osklen e Zara ficaram empatadas na $5^{\underline{a}}$ posição, assim como as marcas Cantão e Nike, que apresentaram $22 \%$ do resultado, ocupando a $6^{\text {a }}$ posição. Apenas $5 \%$ dos respondentes não se lembravam de nenhuma das marcas oferecidas.

\subsubsection{Preferência de lojas para compras}

Na segunda pergunta os respondentes tiveram que marcar a(s) loja(s), se fosse o caso, onde mais compravam. O propósito dessa pergunta foi averiguar quais dessas lojas eram de sua preferência para compra, pois a partir dos resultados obtidos nessa questão é possível traçar uma correlação com as demais perguntas. 


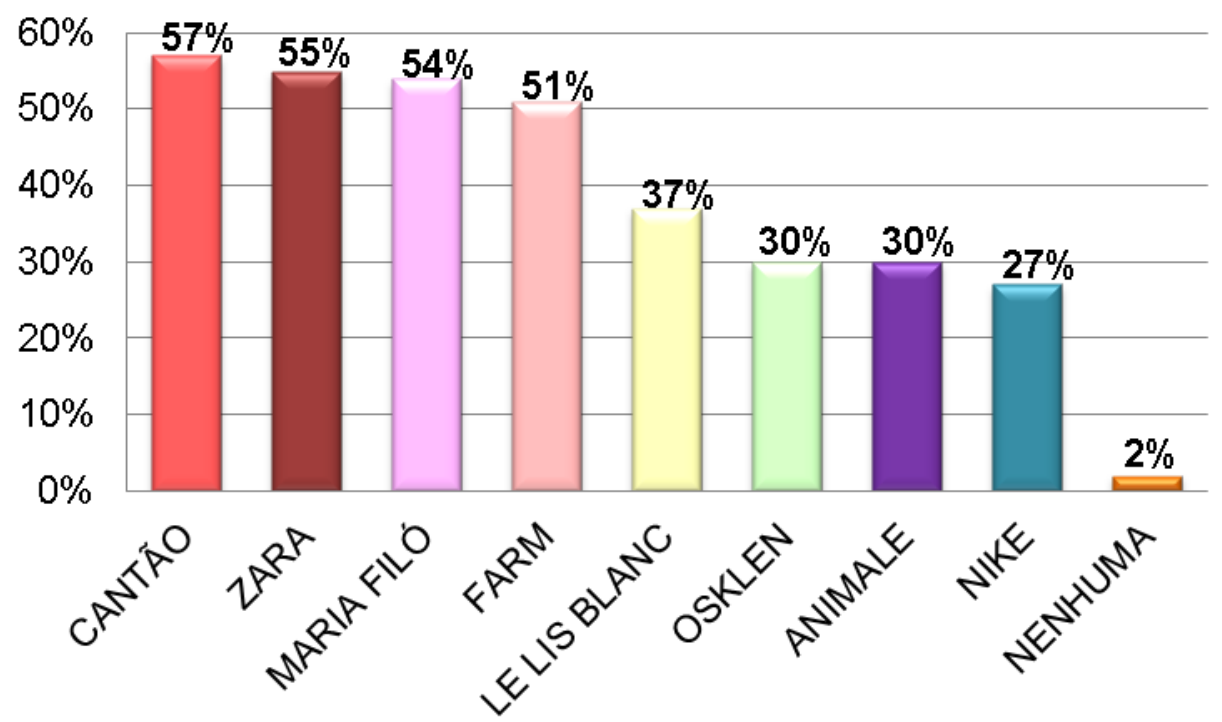

Gráfico 2: Resultado referente à "Q2: Marque onde você mais compra".

Conforme mostra o gráfico 2, a marca Cantão aparece na 1 à posição, com $57 \%$ da preferência das respondentes. Em seguida, ocupando a $2^{\text {a }}$ posição, aparece a marca Zara, representado por $55 \%$ da preferência das respondentes; enquanto que a marca Maria Filó foi citada por 54\% das respondentes, ocupando a $3^{\text {a }}$ posição. Com apenas uma pequena diferença de 3 pontos percentuais da marca anterior, aparece a marca Farm, com $51 \%$, ocupando a $4^{\text {a }}$ posição. A grife Le Lis Blanc foi citada por $37 \%$ das respondentes, ficando com a $5^{\text {a }}$ posição. Houve um empate entre as marcas Osklen e Animale, com 30\% da preferência das respondentes e ambas ocuparam a 6ª posição. A marca Nike foi citada por $27 \%$ das respondentes, ficando na $7^{\text {a }}$ posição e apenas $2 \%$ dos respondentes disseram que não compram em nenhuma das marcas oferecidas.

\subsubsection{Reconhecimento do aroma}

Após instigar a memória olfativa das respondentes, na $1^{\text {a }}$ pergunta, e averiguar se elas eram consumidoras das lojas oferecidas, na $2^{a}$ pergunta, foi perguntado às respondentes se elas achavam que seriam capazes de reconhecer o cheiro da loja onde elas disseram que compram, mesmo não estando lá. Os resultados obtidos podem ser vistos no gráfico abaixo: 


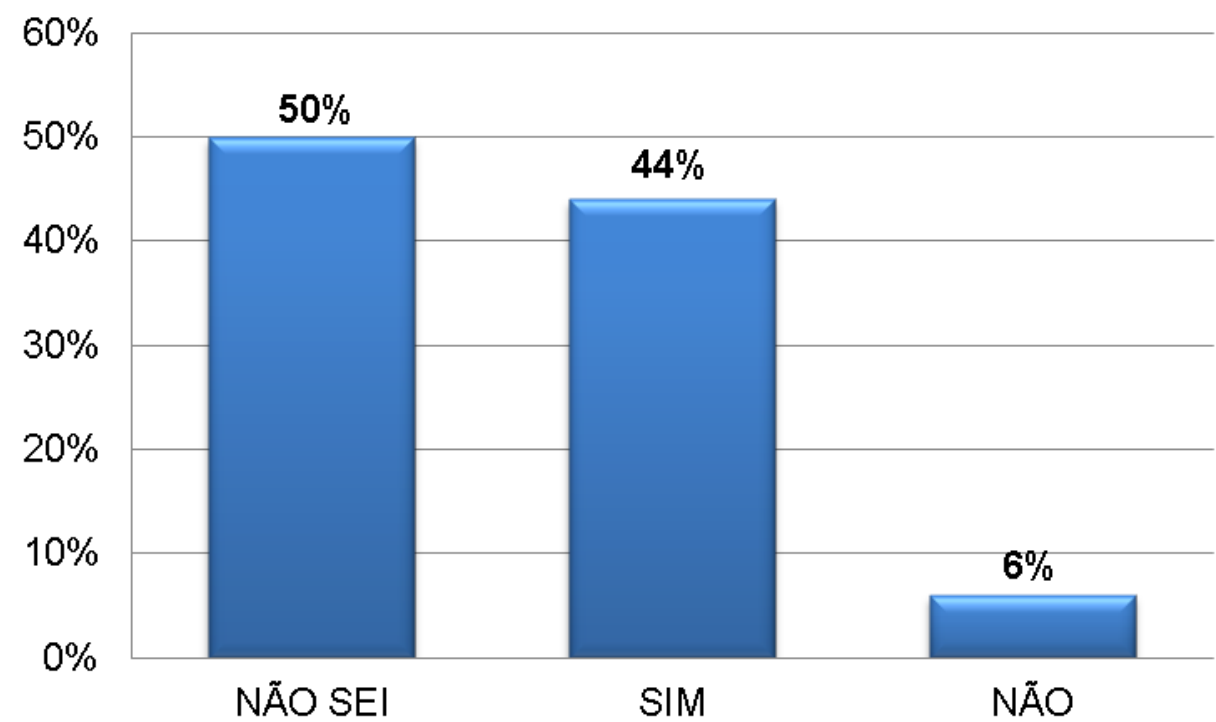

Gráfico 3: Resultado referente à "Q3: Acha que seria capaz de reconhecer o cheiro das lojas onde compra, mesmo não estando lá?".

Metade das respondentes, $50 \%$, respondeu que acham que não saberiam identificar o cheiro da loja; enquanto $44 \%$ delas afirmaram que conseguiriam reconhecer o cheiro da loja mesmo não estando lá e apenas $6 \%$ das respondentes foram categóricas em afirmar que não reconheceriam. Os resultados obtidos nessa questão são importantes para correlacionar posteriormente qual o percentual de pessoas que disseram que não saberiam reconhecer o cheiro da loja e quantos cheiros elas de fato reconheceram, assim como quem disse que reconheceria e quem não reconheceria.

\subsubsection{Resultados do Teste Cego}

Conforme descrito anteriormente na seção de Análise dos Dados, foram oferecidos 4 aromas distintos e 5 opções de lojas para que as respondentes, após sentirem os cheiros apresentados escolhessem de qual loja elas achavam que era o cheiro.

A ordem dos cheiros apresentados era:

Cheiro 1 - FARM

Cheiro 2 - LE LIS BLANC

Cheiro 3 - CANTÃO

Cheiro 4 - MARIA FILÓ 
A tabela abaixo mostra detalhadamente quais foram as opções mais escolhidas pelas respondentes:

\begin{tabular}{|c|c|c|c|c|c|}
\hline \multirow{2}{*}{ LOJAS } & \multicolumn{5}{|c|}{ OPÇÕES ESCOLHIDAS } \\
\cline { 2 - 6 } & CHEIRO 1 & CHEIRO 2 & CHEIRO 3 & CHEIRO 4 & $\%$ \\
\hline MARIA FILÓ & 10 & 20 & 12 & 56 & $52 \%$ \\
\hline CANTÃO & 9 & 10 & 46 & 15 & $42 \%$ \\
\hline FARM & 63 & 9 & 7 & 10 & $58 \%$ \\
\hline LE LIS & 17 & 65 & 11 & 12 & $60 \%$ \\
\hline OSLANC & 9 & 4 & 32 & 15 & N/A \\
\hline Total & & \multicolumn{7}{|c|}{108} & \\
\hline
\end{tabular}

Tabela 1: Opções escolhidas

De acordo com os resultados obtidos, é possível constatar que as respondentes conseguiram, em sua maioria, acertar o respectivo cheiro de cada loja. Apenas no "cheiro 3" representado pela marca Cantão houve uma maior confusão com a marca Osklen, pois segundo a maioria das respondentes que escolheram esta opção o aroma da loja parecia masculino, sendo confundido com o da marca Osklen.

\subsubsection{Número de cheiros que as respondentes acertaram}

Após escolherem qual cheiro as respondentes achavam que correspondiam às marcas, foi perguntado quantos deles elas tinham acertado. 


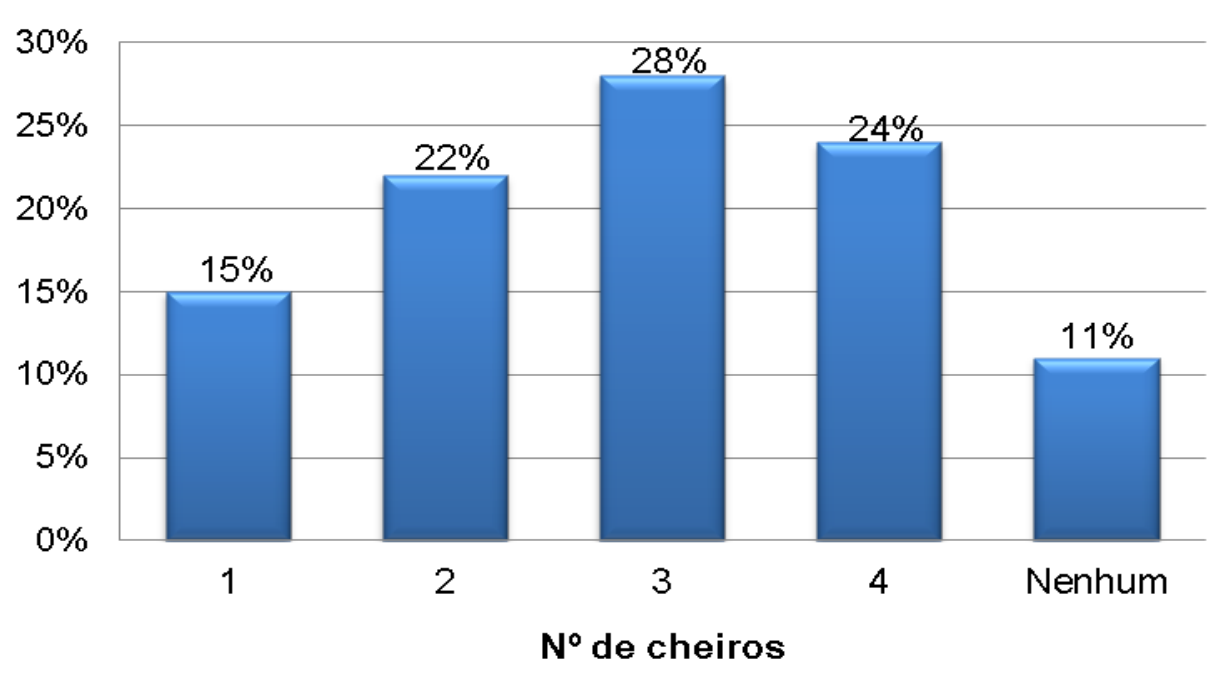

Gráfico 4: Número de cheiros acertados

Os resultados mostram que $15 \%$ das respondentes reconheceram apenas um cheiro, enquanto que $22 \%$ delas foram capazes de reconhcer dois cheiros. Em seguida, aparece 0 maior percentual, correspondente a $28 \%$ das respondentes, que conseguiram reconhecer 3 cheiros. As respondentes que conseguiram reconhecer os 4 cheiros são representadas por $24 \%$ do total e apenas $11 \%$ das respondentes não conseguiram reconhecer nenhum dos quatros cheiros apresentados.

\subsubsection{Lojas que foram mais reconhecidas}

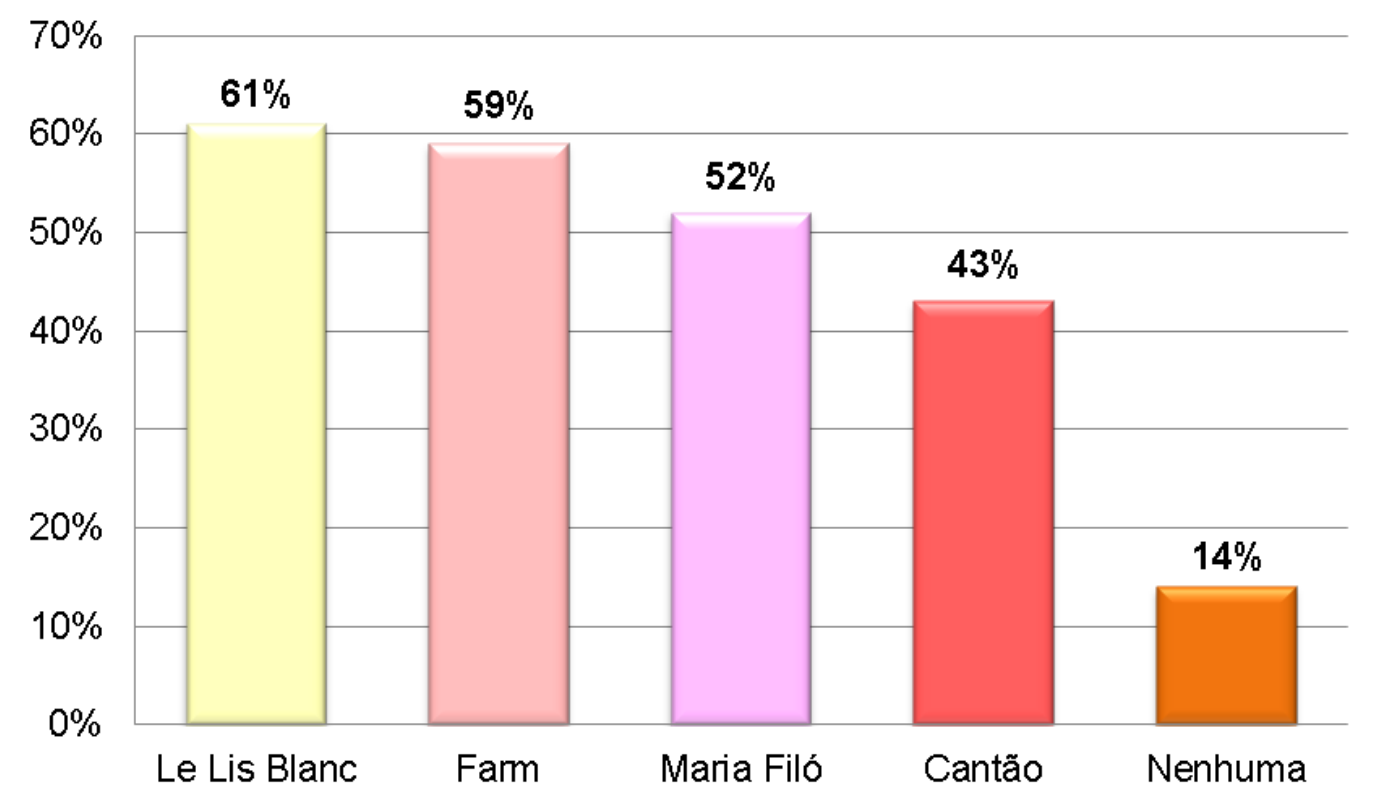

Gráfico 5: Lojas que tiveram aroma mais reconhecido 
A marca Le Lis Blanc foi a que mais as respondentes reconheceram o cheiro, aparecendo com $61 \%$ das respostas, ocupando a $1^{\text {a }}$ posição. Com uma pequena diferença de 2 pontos percentuais, na $2^{\text {a }}$ posição, aparece a marca Farm, com 59\% dos votos. Em seguida, na 3a posição, a marca Maria Filó tem seu cheiro reconhecido por $52 \%$ das respondentes, enquanto a marca Cantão foi reconhecida por $43 \%$ das pessoas. Apenas $14 \%$ das respondentes não conseguiram reconhecer nenhum dos quatros cheiros apresentados.

\subsubsection{Percepção das respondentes com relação aos cheiros}

De modo a entender e conseguir relacionar os resultados obtidos nas perguntas anteriores foi perguntado nessa questão se as respondentes consideravam que tinha acertado o cheiro de acordo com a sua percepção.

O gráfico abaixo nos mostra que apenas $3 \%$ das respondentes disseram que não conseguiram associar o cheiro à loja, pois nunca entraram lá; em contrapartida, $24 \%$ das respondentes afirmaram que não conseguiram associar o cheiro à loja, por ter feito confusão entre os cheiros. Com relação aos resultados positivos da pesquisa, $14 \%$ das respondentes afirmaram ter conseguido reconhecer o cheiro, mesmo tendo ficado confusas com a semelhança entre eles; enquanto $29 \%$ afirmaram terem reconhecido de imediato o cheiro das lojas, pois são clientes da marca e 30\% das respondentes também conseguiram associar o cheiro à loja, pois apesar de não serem clientes, já passaram por elas algumas vezes e conseguiram fazer a associação dos cheiros. Esses últimos dois percentuais são dados importantes, pois ajudam a comprovar a tese de que o marketing olfativo está conseguindo cumprir o seu papel: criar uma identidade olfativa para loja. Isto, porque mesmo que a pessoa não seja cliente da loja, ela consegue reconhecer seu cheiro. 


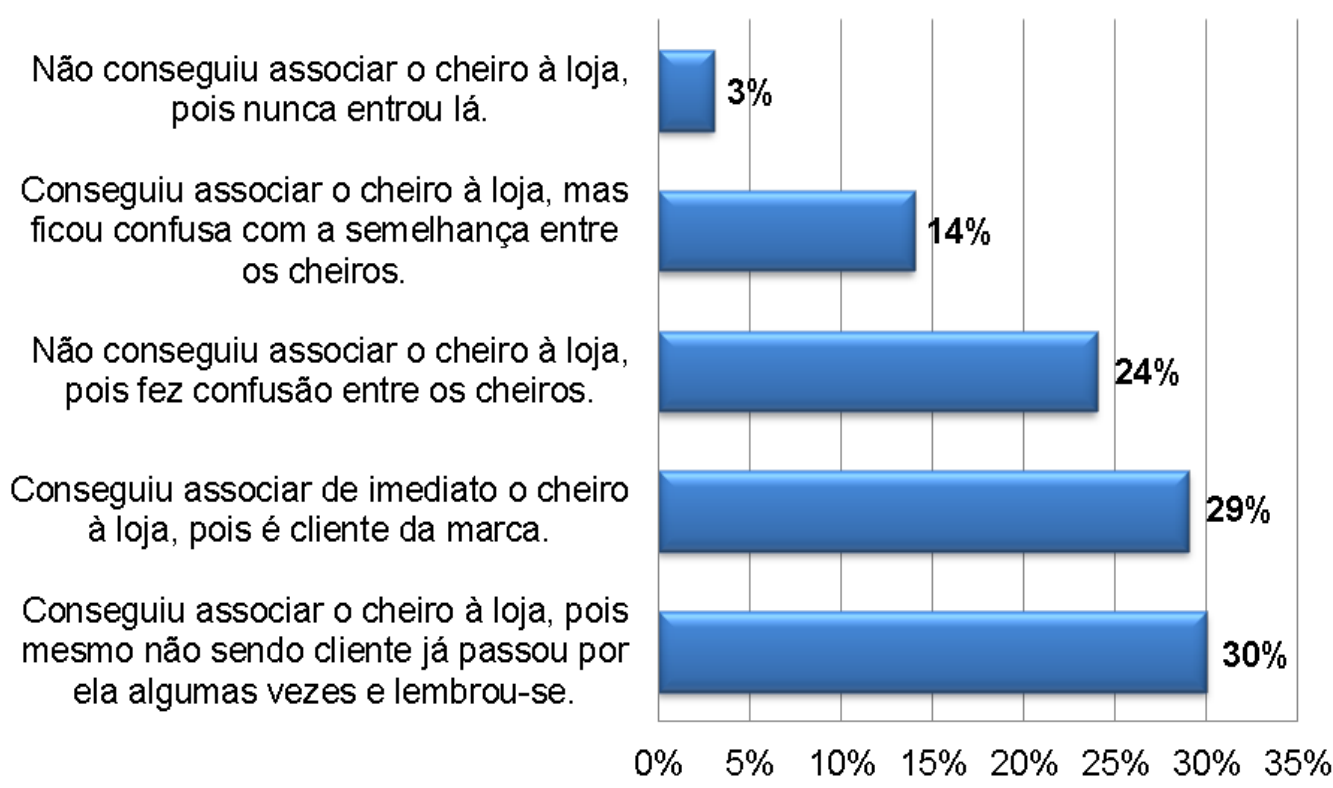

Gráfico 6: Percepção dos respondentes em relação ao cheiros

\subsubsection{Opinião sobre o cheiro das lojas}

Nesta pergunta buscou-se investigar a opinião das respondentes com relação ao cheiro que as lojas utilizam em seu ponto de venda.

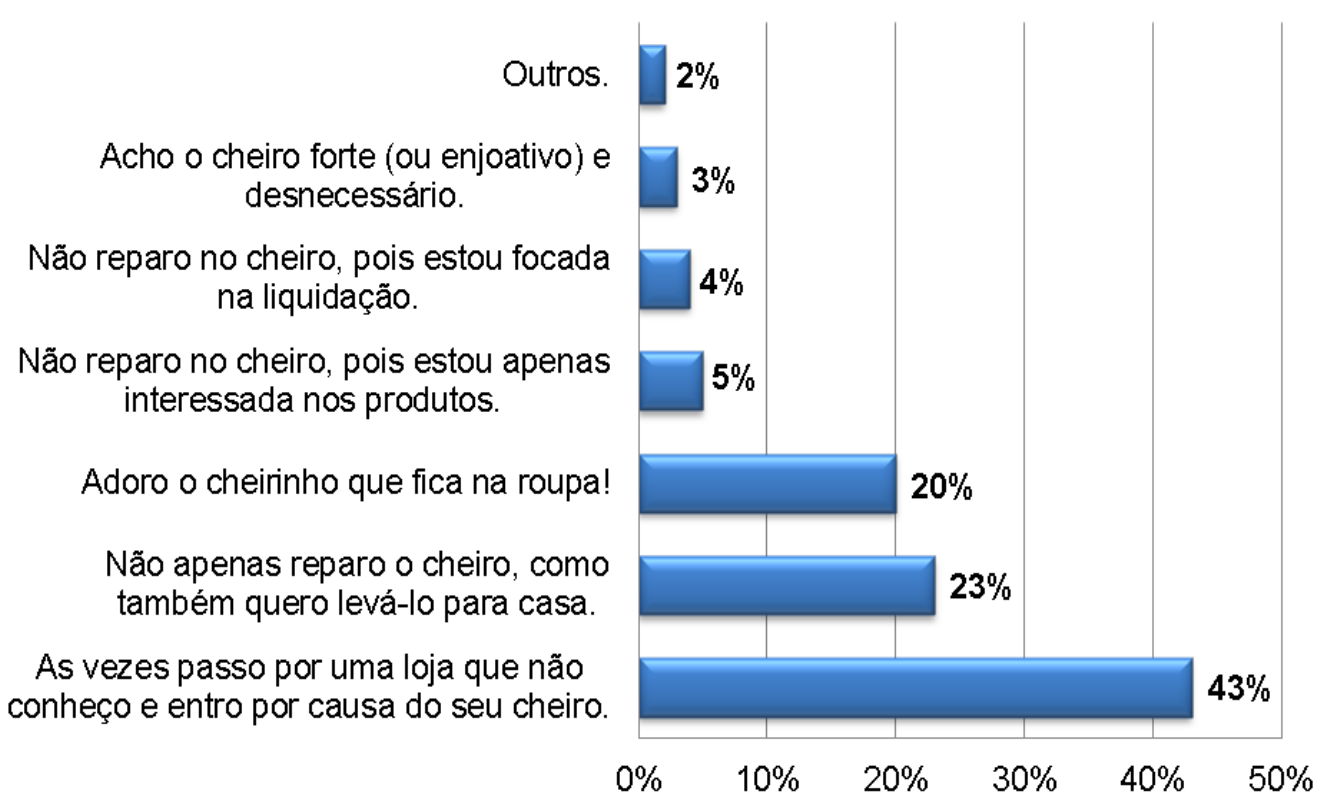

Gráfico 7: Opinião dos respondentes sobre o cheiro das lojas

Apenas $2 \%$ das respondentes optaram pela opção "outros" e disseram que o cheiro da loja é agradável, mas que também depende de qual loja, pois em algumas o cheiro lhes dá dor de cabeça. Juntamente a essas pessoas, 3\% das 
respondentes disseram que consideram o cheiro forte/enjoativo, tornando-o desnecessário. Houve quem dissesse que não reparava no cheiro, pois estava mais focada na liquidação que a loja apresentava, representada por $4 \%$ das respondentes; enquanto $5 \%$ das pessoas responderam que não reparavam no cheiro da loja, pois seu interesse estava voltado para os produtos. No entanto, há quem aprecie o cheirinho das lojas. É o que aponta o resultado representado por $20 \%$ das respondentes que afirmaram que adoram o cheiro que fica na roupa; enquanto $23 \%$ delas disseram que não apenas reparam no cheiro da loja, como também têm vontade de levá-lo para casa. A maior parte das respondentes, representadas por $46 \%$, afirma que às vezes entra em uma loja desconhecida por conta do seu cheiro. Estes resultados fortalecem o que foi abordado ao longo do trabalho a respeito da eficácia do marketing olfativo nas lojas e como ele ajuda a atrair e aguçar mais os sentidos das pessoas.

\subsubsection{Sensações que o cheiro da loja desperta nas pessoas}

Foi pedido que as respondentes marcassem até 3 opções de sensações que o cheiro da loja lhe despertavam.

O resultado pode ser visto no gráfico abaixo:

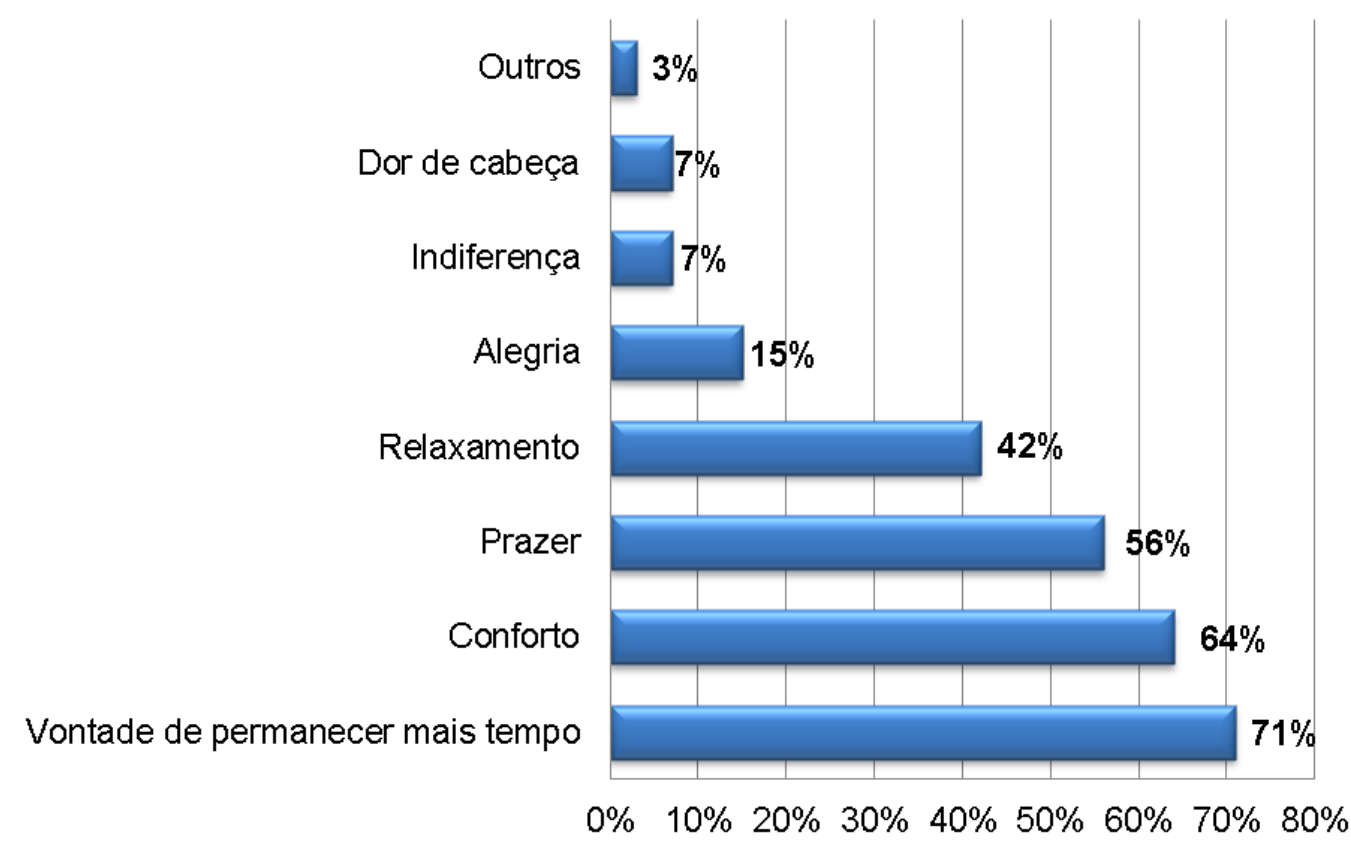

Gráfico 8: Sensações que o cheiro da loja desperta nas pessoas

Um percentual bem baixo, representado por apenas $3 \%$ das respondentes, disse que o cheiro da loja lhe causa mal estar/enjoo; outra apontou uma sensação de envolvimento e a última respondente afirmou que o 
cheiro torna o ambiente da loja mais elegante e sofisticado. As opções "dor de cabeça" e "indiferença" aparecem empatadas, com 7\% das respostas. Em seguida, representado por $15 \%$ das respondentes, aparece a opção "alegria". A opção "relaxamento" aparece com $42 \%$ dos votos, enquanto a opção "prazer" apresenta $56 \%$ da preferência das respondentes. Os maiores percentuais ficam por conta das opções "conforto" e "vontade de permanecer mais tempo", com $64 \%$ e $71 \%$, respectivamente. Mais uma vez, há uma predominância dos resultados positivos na pesquisa, o que nos indica que há uma grande aceitação por parte das respondentes com relação ao cheiro da loja e que ele, em sua maioria, proporciona sensações positivas às pessoas.

\subsubsection{Compraria o aroma de uma das lojas apresentadas? De quais lojas?}

A fim de explorar um pouco mais a opinião das respondentes, foi perguntado se elas comprariam o aroma de uma das lojas para utilizarem em sua casa. A maioria das respondentes, representadas por $77 \%$, responderam que comprariam o aroma, enquanto apenas $23 \%$ responderam que não comprariam. O resultado está ilustrado no gráfico abaixo:

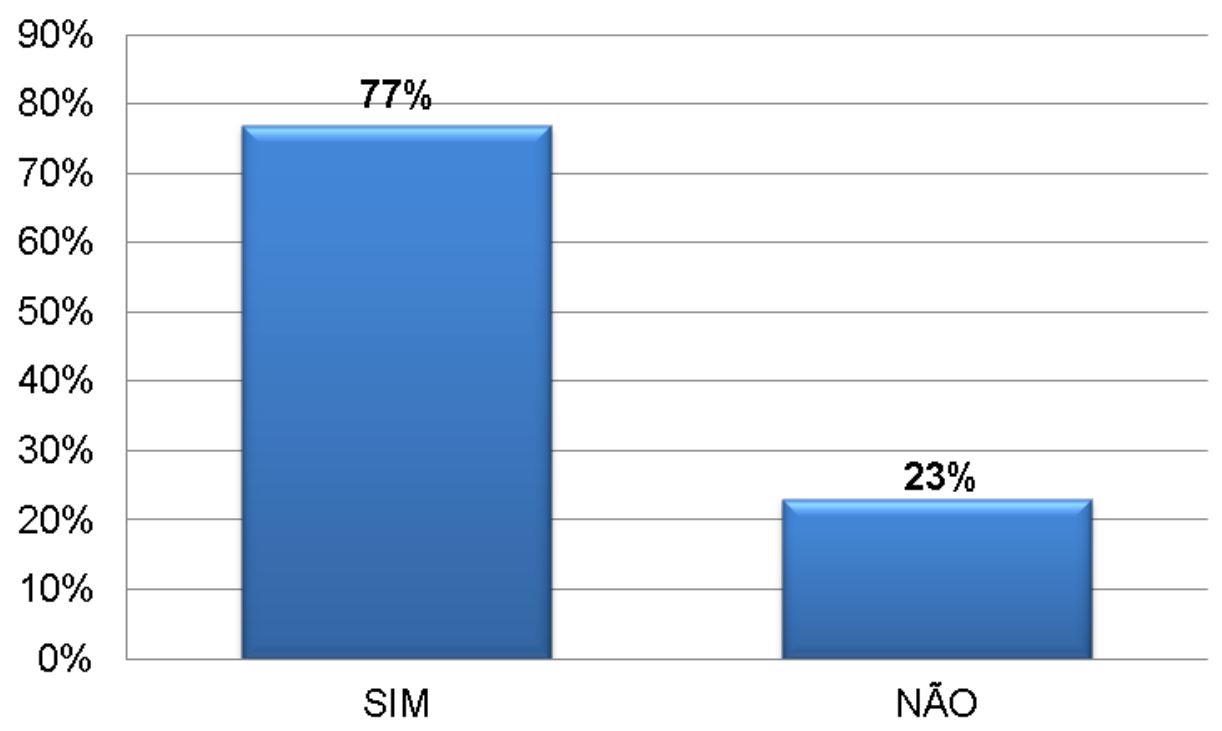

Gráfico 9: Frequência de pessoas que compraria o aroma da loja

Ainda nessa questão, foi perguntado, em caso positivo, qual (is) aroma (s) as respondentes comprariam para utilizarem em suas casas. 


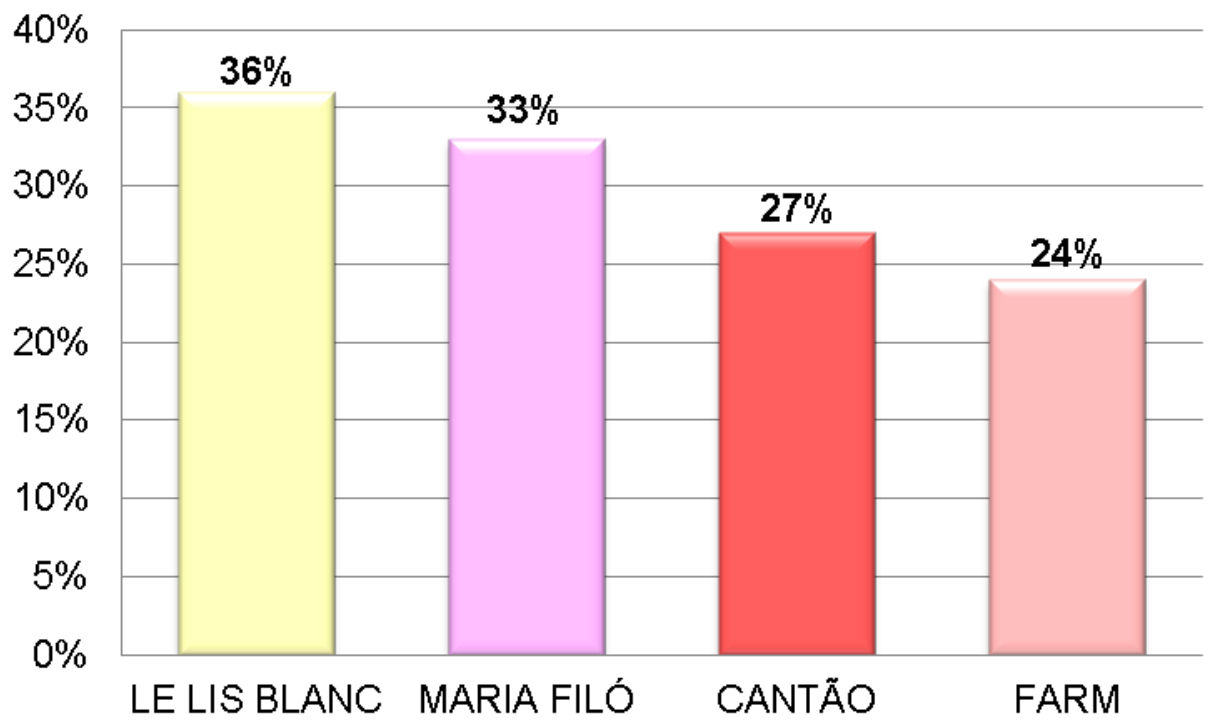

Gráfico 10: Lojas mais escolhidas pelas pessoas para compra do aroma

O resultado aponta que a marca Le Lis Blanc aparece na $1^{\text {a }}$ posição, com $36 \%$ das respostas, como a loja que as respondentes comprariam o aroma para ter em casa. $\mathrm{Na} 2^{a}$ posição, com $33 \%$ dos votos, aparece a marca Maria Filó. Em seguida, com $27 \%$ dos votos a marca Cantão fica na $3^{\text {a }}$ posição e por último, com $24 \%$ dos votos, aparece a marca Farm.

\subsubsection{O que acha da estratégia das lojas em aromatizarem seus pontos de venda}

Nesta questão foi pedido que as respondentes marcassem qual a melhor opção correspondia ao que elas achavam sobre a estratégia das lojas em aromatizarem seus pontos de venda.

Nenhuma das 108 respondentes assinalou a opção de que não gostavam do cheiro, pois eles poderiam incomodar quem têm problemas respiratórios. Apenas $5 \%$ delas respondeu que o cheiro, se for exagerado, pode causar mal estar. A grande maioria das respostas voltou-se para as opções "acho uma ótima estratégia, pois atrai os consumidores a entrarem no ponto de venda, tornando o ambiente da compra mais agradável", representado por $46 \%$ das respostas e para a opção "acho uma estratégia eficiente, pois ajuda as lojas a reafirmarem a identidade e o conceito da marca", com $49 \%$ dos votos.

O gráfico abaixo ilustra os resultados da pergunta: 


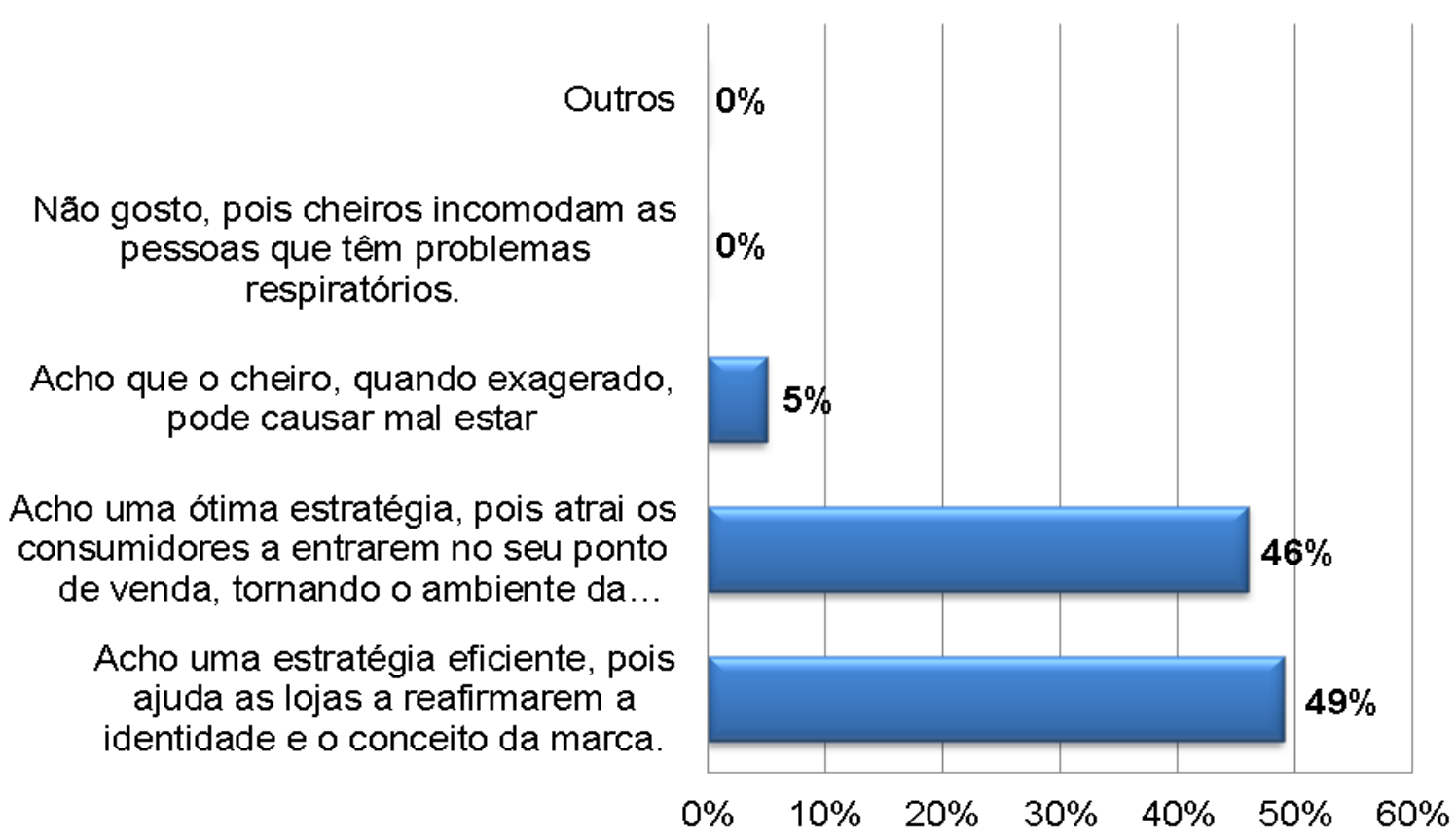

Gráfico 11: Opinião das respondentes sobre a estratégia do marketing olfativo

\subsubsection{Idade}

Por fim, o gráfico abaixo apresenta a idade das respondentes da pesquisa.

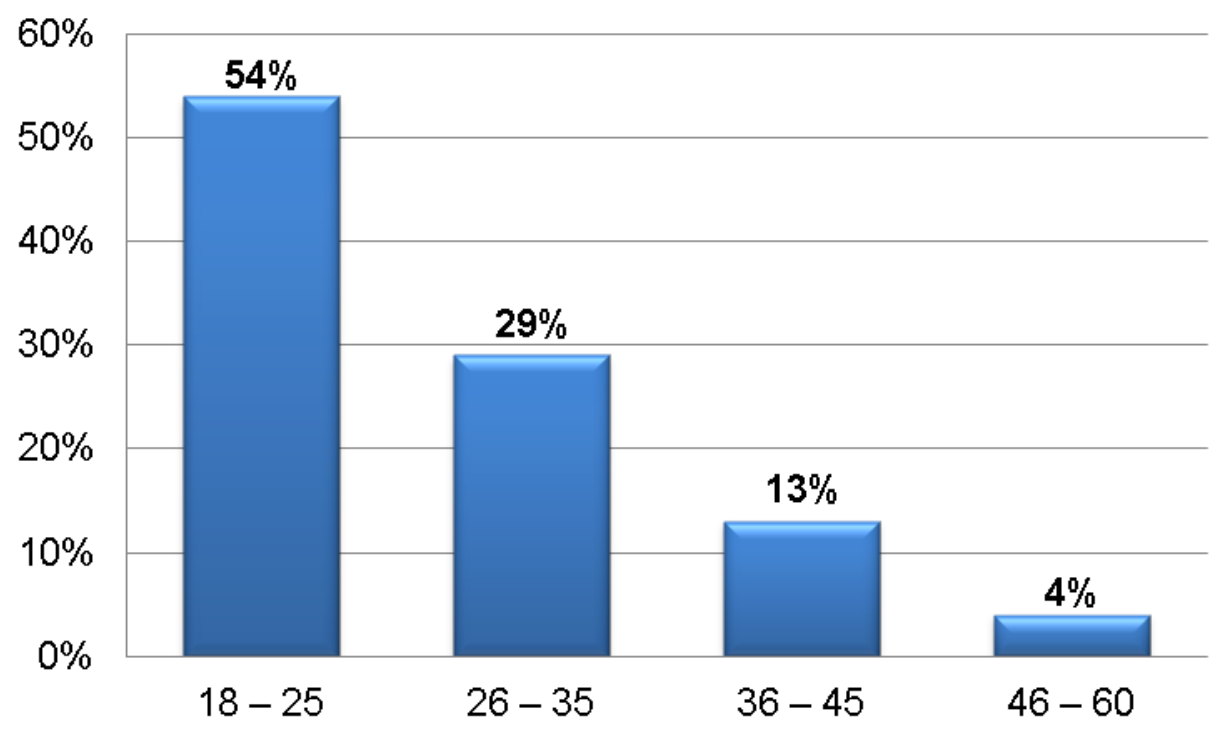

Gráfico 12: Idade

A maioria das respondentes, representadas por $54 \%$ das pessoas, tinham idade entre $18-25$ anos. Em seguida, aparece com $29 \%$ das responstas a faixa etária entre $26-35$ anos. Apenas $13 \%$ das respondentes tinham idade entre 36 
- 45 anos e um número menor ainda é representado pelas respondentes com idade entre 46 - 60 anos, representado por $4 \%$ das respostas.

\subsection{Análises Cruzadas}

Foi feita uma análise cruzada entre alguns dados obtidos no questionário a fim de se estabelecer algumas correlações entre as respostas fornecidas pelas respondentes.

\subsubsection{Acha que seria capaz de reconhecer os cheiros $x$ quantos cheiros acertou}

Cruzando os dados referentes às perguntas: "Acha que seria capaz de reconhecer os cheiros das lojas onde compra, mesmo não estando lá?" com os dados da pergunta "quantos cheiros acertou?" obtemos os gráficos abaixo:

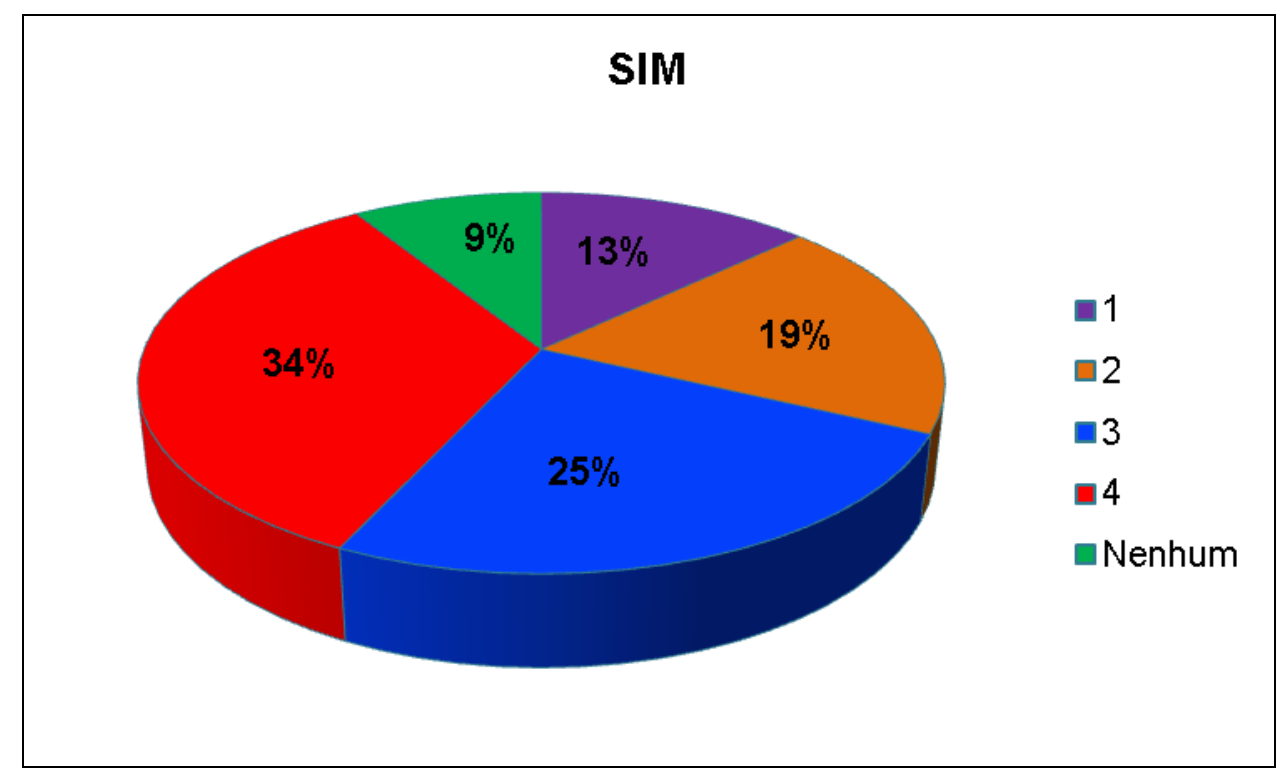

Gráfico 13: Análise cruzada: Escolha da opção SIM

Das pessoas que marcaram a opção "sim" para a pergunta se acham que conseguiriam reconhecer o cheiro, o gráfico nos mostra que o percentual mais alto, representado por $34 \%$ dessas pessoas conseguiram reconhecer os 4 cheiros apresentados, enquanto houve casos em que a pessoa marcou a opção "sim", mas acertou apenas 3 cheiros (25\%), 2 cheiros (19\%) e 1 cheiro (13\%). 
Este resultado nos mostra que a maioria das pessoas que achou que conseguiria reconhecer os cheiros conseguiu reconhecer, em sua maioria, os 4 cheiros.

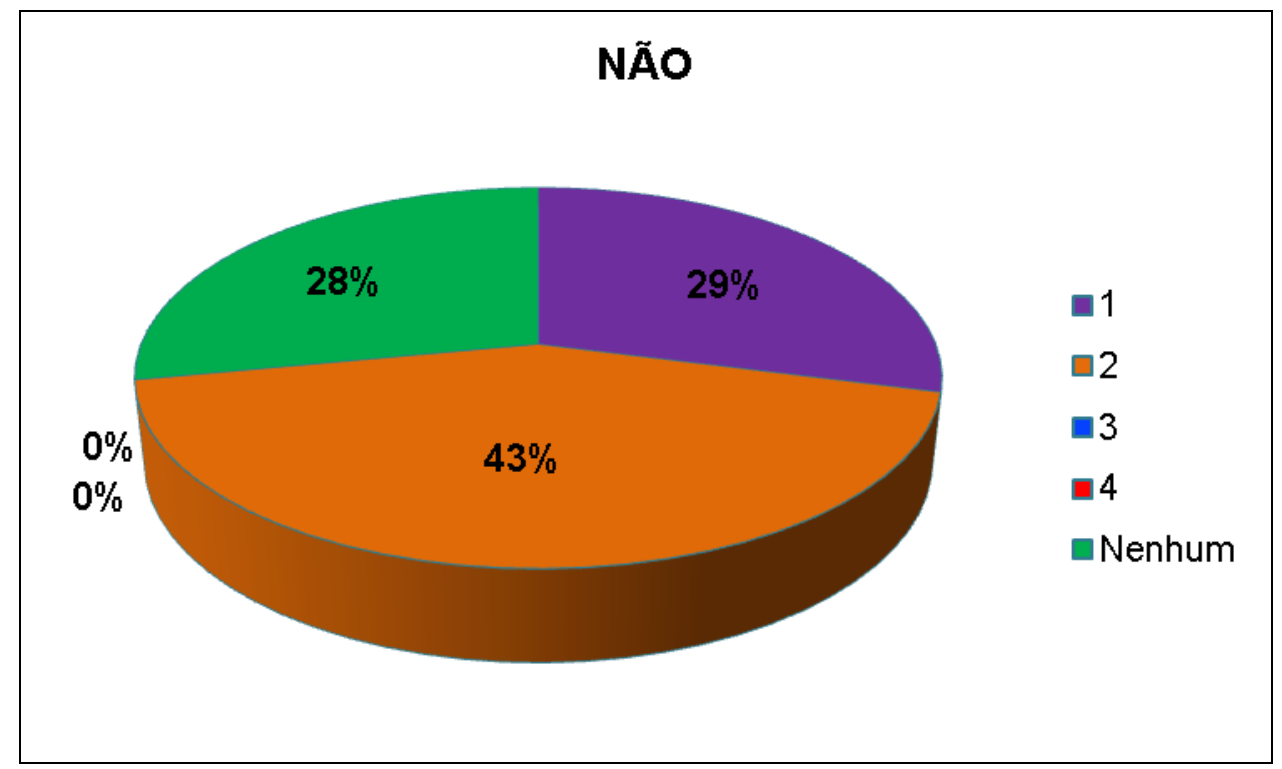

Gráfico 14: Análise cruzada: Escolha da opção NÃO

O gráfico nos apresenta os resultados das pessoas que marcaram que não conseguiriam reconhecer os cheiros apresentados. O maior percentual, representado por $43 \%$ dos respondentes, conseguiu surpreendentemente acertar pelo menos 2 cheiros. No entanto, $29 \%$ dos respondentes conseguiu acertar apenas 1 cheiro; enquanto $28 \%$ dos respondentes que assinalaram a opção "não" de fato não conseguiram reconhecer nenhum cheiro. Houve a ocorrência de dois resultados representados por $0 \%$, que significam que esses respondentes não conseguiram reconhecer nem 3 e tão pouco os 4 cheiros. 


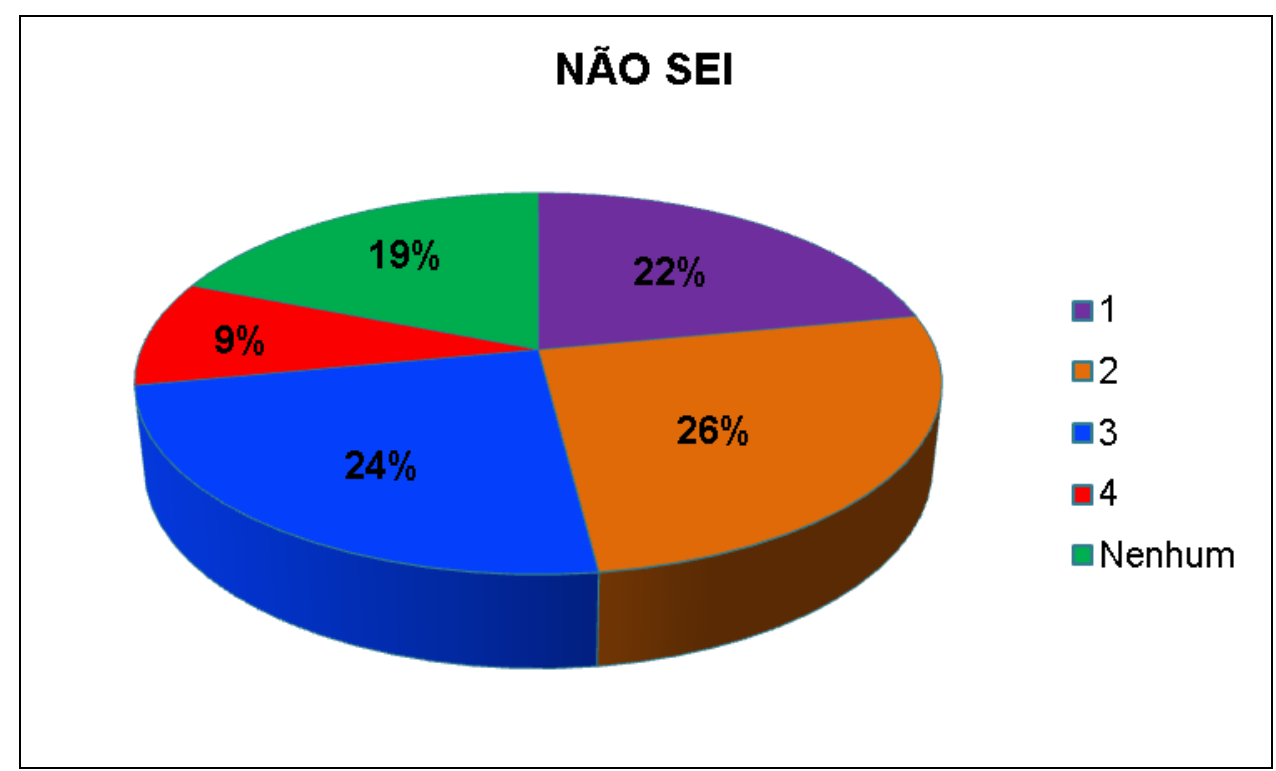

Gráfico 15: Análise Cruzada: escolha da opção NÃO SEI

O gráfico apresenta as respostas das pessoas que marcaram a opção "não sei" quando perguntadas se achavam que reconheceriam o cheiro das lojas apresentadas. A partir dos resultados obtidos, temos que $22 \%$ das respondentes reconheceram apenas 1 cheiro; enquanto que 26\% delas reconheceram 2 cheiros. Em seguida, com 24\% dos votos, observamos que estas respondentes conseguiram reconhecer 3 cheiros; apenas $9 \%$ conseguiram reconhecer os 4 cheiros e $19 \%$ não reconheceram nenhum cheiro.

Fazendo uma análise geral, os resultados podem ser classificados como interessante, pois quem considerava que não conseguiria acertar nada, conseguiu acertar pelo menos 2 cheiros; quem afirmou com certeza que reconheceria os cheiros, de fato reconheceu e quem respondeu "não saber" se reconheceria também reconheceu, em sua maioria, pelo menos 2 cheiros. 


\subsubsection{Onde mais compra $x$ capacidade de percepção das pessoas com relação aos cheiros}

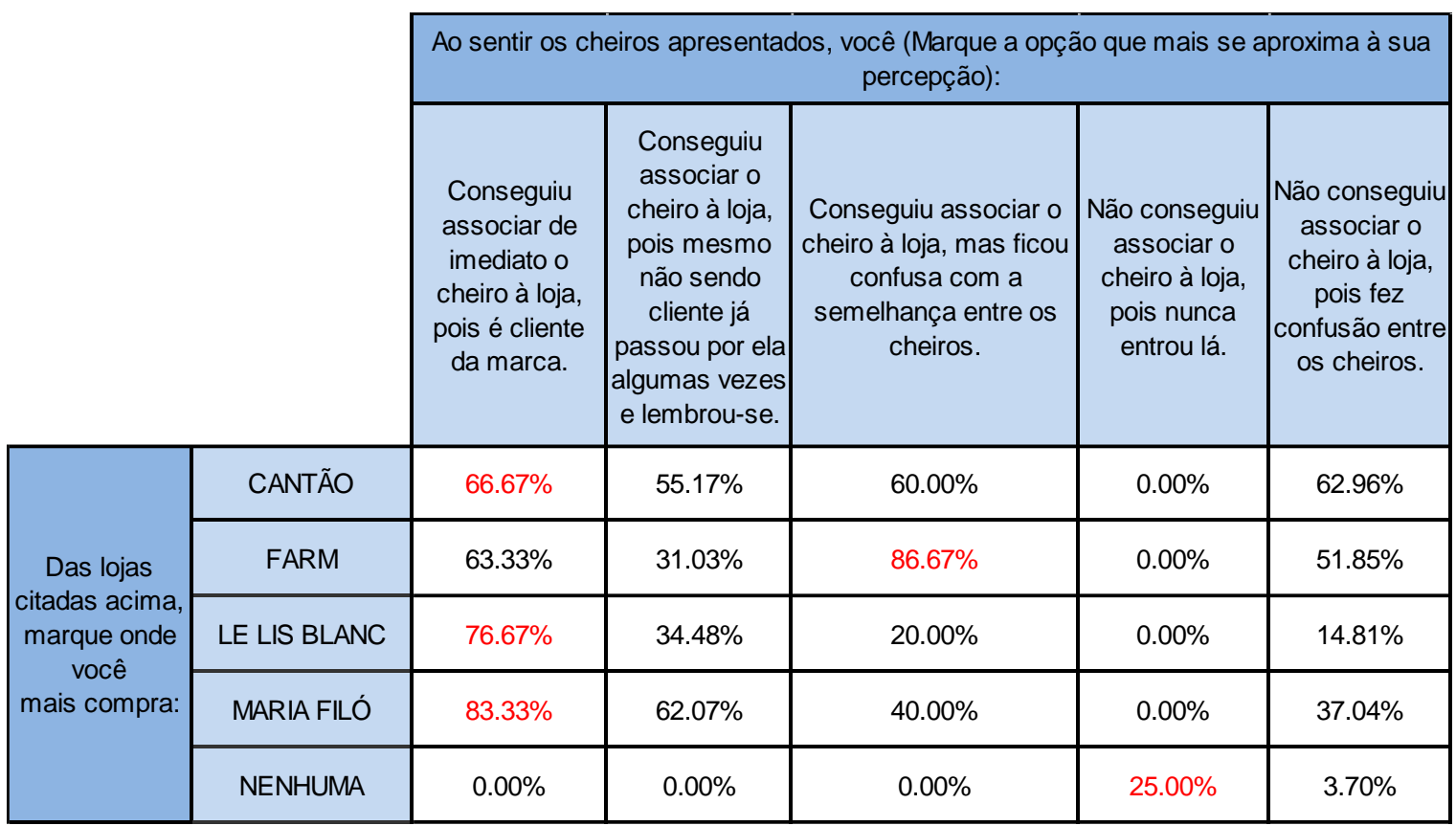

Tabela 2: Análise cruzada dos resultados entre "onde mais compra" e "percepção das respondentes"

A tabela acima apresenta os resultados do cruzamento das perguntas onde as pessoas mais compram e quais as opções mais se aproximavam de sua percepção ao sentirem os cheiros das lojas. O objetivo desse cruzamento de dados não é saber quantos cheiros a pessoa acertou, mas sim qual foi sua percepção após sentir os cheiros.

Entre as opções fornecidas, o maior percentual das respondentes que disseram comprar na Cantão, 66,67\%, afirmam que conseguiram associar imediatamente o cheiro à loja, pois são clientes da marca.

Já $86,67 \%$ das respondentes que afirmaram comprar mais na Farm até conseguiram associar o cheiro à loja, mas muitas ficaram confusas com a semelhança entre os cheiros apresentados. Ainda assim, um percentual alto, representado por $63,33 \%$ das respondentes afirmaram que conseguiram reconhecer o cheiro da loja, pois são clientes da marca.

As marcas Le Lis Blanc e Maria Filó também apresentaram altos percentuais, representados por $76,67 \%$ e $83,33 \%$, respectivamente, referentes ao fato das pessoas reconhecerem de imediato o cheiro à loja, pois eram clientes da marca. 
As pessoas que marcaram que não compram em nenhuma das lojas, consequentemente, responderam não terem conseguido associar o cheiro à loja, por nunca terem entrado lá.

Através dessa análise conseguimos perceber que a maioria das pessoas que respondeu que compra nas lojas foi capaz de reconhecer conscientemente o cheiro das mesmas e não marcando de forma aleatória, o que nos infere que o aroma da loja é marcante na sua memória olfativa. Também foi possível perceber, através dos altos percentuais, que muitas pessoas, mesmo não reconhecendo imediatamente o cheiro à loja, conseguiram associá-lo à loja pelo simples fato de já terem passado por ela algumas vezes e terem se recordado do cheiro.

\subsubsection{Quantos cheiros acertou x reação pessoal ao cheiro}

Ao se cruzar as perguntas "quantos cheiros acertou" com a "reação que mais combinava com a percepção da pessoa" foi possível analisar se a reação das pessoas que tiveram mais ou menos acertos. Essa análise nos ajuda a inferir que quem escolheu uma opção positiva, conseguiu acertar um alto número de cheiros, pois reparam no aroma das lojas.

Os resultados podem ser vistos na tabela abaixo:

\begin{tabular}{|c|c|c|c|c|c|c|c|}
\hline & & & & $\overline{a c}$ & & & \\
\hline & & 1 & 2 & 3 & 4 & NENHUM & Total \\
\hline & $\begin{array}{l}\text { Adoro o cheirinho que } \\
\text { fica na roupa! }\end{array}$ & 4 & 5 & 5 & 3 & 7 & 24 \\
\hline & $\begin{array}{c}\text { Não apenas reparo o } \\
\text { cheiro, como também } \\
\text { quero levá-lo para casa. }\end{array}$ & 7 & 4 & 5 & 11 & 0 & 27 \\
\hline $\begin{array}{l}\text { Quando você entra em } \\
\text { uma loja que tem seu }\end{array}$ & $\begin{array}{c}\text { As vezes passo por uma } \\
\text { loja que não conheço e } \\
\text { entro por causa do seu } \\
\text { cheiro. }\end{array}$ & 6 & 12 & 16 & 8 & 5 & 47 \\
\hline $\begin{array}{l}\text { opções abaixo mais } \\
\text { combina com... }\end{array}$ & $\begin{array}{l}\text { Não reparo no cheiro, } \\
\text { pois estou apenas } \\
\text { interessada nos } \\
\text { produtos. }\end{array}$ & 2 & 3 & 0 & 0 & 1 & 6 \\
\hline & $\begin{array}{l}\text { Não reparo no cheiro, } \\
\text { pois estou focada na } \\
\text { liquidação. }\end{array}$ & 1 & 3 & 0 & 0 & 0 & 4 \\
\hline & $\begin{array}{c}\text { Acho o cheiro forte (ou } \\
\text { enjoativo) e } \\
\text { desnecessário. }\end{array}$ & 0 & 2 & 0 & 0 & 2 & 4 \\
\hline & Outros. & 0 & 0 & 0 & 1 & 1 & 2 \\
\hline
\end{tabular}


Tabela 3: Análise cruzada dos resultados entre "quantos cheiros acertou" e "reação pessoal ao cheiro"

Analisando a tabela, 47 respondentes afirmaram que entram muitas vezes entram em lojas que não conhecem, apenas por conta do cheiro. Desse número, 16 delas acertaram 3 cheiros.

No entanto, as respondentes que escolheram uma opção negativa, sendo o maior número representado por 6 delas, afirmaram não repararem no cheiro e consequentemente apresentaram um baixo número de acerto nas respostas.

Portanto, a tendência é que a memória olfativa seja mais presente naquelas pessoas que são receptivas aos cheiros. Por outro lado, as pessoas que não reagem da mesma forma positiva, tem a tendência a acertar menos os cheiros, pois não estão atentas a eles. 


\section{Conclusões e recomendações para novos estudos}

Este trabalho pretendeu investigar a estratégia de aromatização utilizada por quatro lojas de varejo de vestuário feminino. Para isso, foi feito um teste cego com 108 mulheres para avaliar se elas conseguiam reconhecer o cheiro das lojas mesmo não estando lá ou não sendo necessariamente consumidoras dessas lojas. O propósito do teste é provar que as marcas possuem uma identidade olfativa marcante e que por conta dessa estratégia, elas conseguem aumentar sua percepção de valor perante as pessoas.

O estudo atingiu seu objetivo de investigar se a utilização de uma identidade olfativa conquista um espaço duradouro na memória dos consumidores, pois foi provado que mesmo que as pessoas não sejam consumidoras de determinada loja, elas conseguem, em sua maioria, reconhecer o cheiro das mesmas.

Os resultados do teste nos mostram que as marcas Maria Filó e Le Lis Blanc foram apontadas, com o maior percentual, como as marcas que as pessoas mais lembram quando perguntadas sobre cheiros marcantes.

Ao serem questionadas em quais lojas consumiam mais, as respondentes apontaram as lojas Cantão e Zara como suas preferidas.

Metade das respondentes afirmou, ao serem questionadas se seriam capazes de reconhecer o aroma das lojas onde consumiam mesmo não estando lá, que não sabiam se conseguiriam reconhecer o aroma; o que foi provado através do cruzamento dos dados que essas respondentes, apesar de acharem que não seriam capazes, reconheceram em sua maioria 2 a 3 cheiros do total.

O teste mostrou que a maioria das pessoas, representadas por $28 \%$ das respondentes, conseguiu reconhecer pelo menos 3 cheiros do total, um número alto considerando que foram oferecidos 4 cheiros. 
A marca Le Lis Blanc despontou como a marca que tem o cheiro mais marcante, sendo a mais reconhecida pelas respondentes, seguida das marcas Farm, Maria Filó e Cantão.

Ao serem questionadas sobre sua percepção após sentirem o aroma das lojas, as respondentes afirmaram conseguir associá-lo à loja, seja pelo fato de serem clientes da marca ou pelo fato de apesar de não serem clientes, já terem passado por ela algumas vezes, lembrando-se do seu cheiro.

Quando questionadas a respeito de sua opinião sobre o cheiro das lojas, $43 \%$ das respondentes, a maioria, afirmaram que passam por uma loja que não conhecem e entram apenas por conta do seu cheiro. Isso nos mostra que o fato das lojas aromatizarem o seu ponto de venda é uma estratégia eficaz e que consegue atrair as pessoas para dentro do seu ponto de venda.

As principais sensações que o cheiro desperta nas pessoas são: vontade de permanecer mais tempo no ambiente; conforto; prazer e relaxamento.

Com o intuito de averiguar se os cheiros são do agrado das pessoas e de quais lojas elas levariam o cheiro para ter em suas casas, $77 \%$ das respondentes se mostrou favorável a comprá-los, sendo que a maioria respondeu que levaria o cheiro da Le Lis Blanc.

Foi possível perceber que para a grande maioria das respondentes a estratégia das lojas em aromatizar seus pontos de venda é eficiente, pois além de atrair os consumidores para a loja, torna o ambiente da compra mais agradável e ajuda as lojas a reafirmarem a identidade o conceito da marca.

Foram cruzados alguns dados com o intuito de se conseguir fazer uma análise um pouco mais detalhada dos resultados. Os resultados obtidos nessas análises nos mostram, de forma geral, que as pessoas que apresentaram reações positivas ao cheiro das lojas conseguem acertá-los de forma consciente e que estas possuem uma memória olfativa mais aguçada do que as pessoas que se mostraram não serem tão receptíveis aos cheiros. 


\subsection{Sugestões e recomendações para novos estudos}

O presente estudo pode ser utilizado por lojas de varejo que ainda não utilizam a estratégia de aromatizar seus ambientes, pois foi comprovado que quando há a presença de um cheiro agradável no ponto de venda, as pessoas têm mais vontade de permanecer na loja, despertando sensações como prazer, conforto e relaxamento. Dessa forma, ao permanecerem mais tempo em um ambiente aromatizado, a tendência é que essas pessoas consumam mais e queiram levar um pouco dessa experiência para casa, ao comprarem o aromatizador da loja para ser utilizado em suas casas.

Além disso, as marcas que possuem um aromatizador próprio conseguem construir uma identidade olfativa marcante a ponto de que, até mesmo quem não é cliente fiel daquela loja conseguir reconhecer o cheiro por ter passado algumas vezes por ela.

Outros estudos podem ser feitos abrangendo lojas que não sejam apenas de vestuário de varejo, como lojas de sapatos e lojas de móveis, que através dos estudos realizados também utilizam um aroma próprio em seus pontos de venda.

Também pode ser feito um estudo avaliando os aromas fabricados que despertam a vontade de comer, como o caso da Kopenhagen, Outback, Subway e até mesmo os cinemas com o cheiro da pipoca. 


\section{Referências Bibliográficas}

BERNARDINO, E. C. [et al.]. Marketing de Varejo - 4 ${ }^{a}$ ed. - Rio de Janeiro: Editora FGV, 2011.

Biomist. Homepage institucional. Disponível em: <http://www.biomist.com.br >. Acesso em 02 de Setembro de 2015

CASTRO, M.C. Homepage institucional. Disponível em: <http://www.casamay.com.br/> Acesso em 16 de Setembro de 2015.

CHURCHILL, Jr., Gilbert A.; PETER. J. Paul. Marketing, Criando valor para os clientes. Tradução de Cecília Camargo Bartalotti e Cidd Knipel Moreira. $2^{\underline{a}}$ ed. São Paulo: Editora Saraiva, 2000.

DEVECCHI, R. O marketing olfativo no varejo. Rai Industrial, São Paulo. Disponível em: <http://www.raiingredients.com.br/extra1.pdf>. Acesso em: 29 de Agosto de 2015.

DUNNE, Patrick.; LUSCH, Robert F. Retailling. $3^{\text {a }}$ ed. Hinsdale: Dryden Press, 1999 .

FARKAS, Fátima L. Marketing Olfativo: guia de aromatização de ambientes. $1^{\underline{a}}$ ed. São Paulo: Editora Senac, 2013.

KOTLER, Philip.; KELLER, Kevin Lane. Administração de marketing. Tradução de Mônica Rosemberg, Cláudia Freire e Brasil Ramos Fernandes. $12^{a}$ ed. São Paulo: Prentice-Hall, 2000.

LA VIE AROMAS. Porque aromatizar? Homepage institucional, 2014. Disponível em: <http://laviearomas.com.br/\#porque_aromatizar>. Acesso em 17 de Agosto de 2015. 
LINDSTROM, Martin. Buy.ology: Truth and Lies About Why We Buy. 1a ed. New York: Doubleday, 2008

MILLIMAN, Ronald E. "The Influence of Backgrounf Music on the Behaviour of Restaurant Patrons, 1986. Disponível em: Journal of Consumer Research.

MIRANDA, Roberto Lira. Marketing do varejo e alianças estratégicas com a indústria. Rio de Janeiro: Qualitymark Editora, 1997.

PARENTE, Juracy. Varejo no Brasil. 1a ed. São Paulo: Atlas, 2007.

Scent Marketing Institute. Homepage Institucional. Disponível em: <http://www.scentmarketing.org >. Acesso em: 20 de outubro de 2015.

SCHMITT, Bernd. H. Experimental Marketing: How to get customers to sense, feel, think, act and relate to your company and brands. $1^{\text {a }}$ ed. New York. Free Press, 1999.

SIMÕES, K. Aromas que vendem. Revista PEGN, São Paulo, 2009. Disponível em: <http://revistapegn.globo.com/Empresasenegocios/0,19125,ERA463263-24911,00.html>. Acesso em: 29 de Agosto de 2015

SOLOMON, Michael R. O Comportamento do consumidor: Comprando, possuindo e sendo. Tradução de Luiz Claudio de Queiroz Faria. 9a ed. Porto Alegre: Bookman, 2011.

Studio d'essences. Homepage institucional. Disponível em: <http://studiodessences.com.br/home>. Acesso em: 15 de Outubro de 2015.

TRUCOM, C. Aromaterapia - sistema límbico, o coração da mente, 2013. Disponível em: < https://www.docelimao.com.br/site/terapias/86terapias/1455-aromaterapia-sistema-limbico-o-coracao-da-mente.html > Acesso em 02 de Setembro de 2015.

ZIKMUND, William G. Princípios da pesquisa de marketing. Tradução de Cristina Bacellar. $2^{\underline{a}}$ ed. São Paulo: Thomson, 2006. 
WIDRICH. L. Por que o facebook é azul? Revista dos Administradores, São Paulo, 3 de jun. 2013. Disponível em: < http://www.administradores.com.br/noticias/marketing/por-que-o-facebook-eazul/76562/>. Acesso em: 08 de Setembro de 2015. 


\section{Anexo 1 - Questionário}

\section{QUESTIONÁRIO - TESTE CEGO}

Mesmo que você nunca tenha comprado em determinada loja, você provavelmente já ouviu falar dela e/ou já deve ter passado em frente a ela. Este questionário é uma pesquisa de opinião que servirá como base para elaboração de uma pesquisa na área de Marketing.

\section{PARTE: FILTRO}

1 - Quando você pensa no "cheiro da loja", qual das marcas abaixo Ihe vem à cabeça? (Marque todas as que desejar):

$\begin{array}{lll}\text { ( ) } \text { ANIMALE } & (\text { ) LE LIS BLANC } & (\text { ) OSKLEN } \\ (\quad) \text { CANTÃO } & (\quad) \text { MARIA FILÓ } & (\text { ) ZARA } \\ (\quad) \text { FARM } & (\quad) \text { NIKE } & \end{array}$

2 - Das lojas citadas acima, marque onde você mais compra:

$\begin{array}{lll}\text { ( ) } \text { ANIMALE } & (\text { ) LE LIS BLANC } & (\text { ) OSKLEN } \\ (\quad) \text { CANTÃO } & (\quad) \text { MARIA FILÓ } & (\quad) \text { ZARA } \\ (\quad) \text { FARM } & (\quad) \text { NIKE } & \end{array}$

3 - Todas as lojas citadas têm seu cheiro próprio, o que chamamos de Identidade Olfativa. Você acha que seria capaz de reconhecer o cheiro das lojas onde compra, mesmo não estando lá?

( ) Sim ( ) Não ( ) Não sei

\section{2ª PARTE: TESTE CEGO}

Abaixo há 5 opções de lojas, mas serão apresentados apenas o cheiro de 4 delas. De acordo com a ordem que os cheiros the forem apresentados, assinale a qual loja ele corresponde. 


CHEIRO 1:
$\left(\begin{array}{l}\text { ( ) MARIA FILÓ } \\ (\text { ) CANTÃO } \\ (\text { ) FARM } \\ (\text { ) LE LIS BLANC } \\ (\text { ) OSKLEN }\end{array}\right.$

\section{CHEIRO 2:}

( ) MARIA FILÓ

( ) CANTÃO

( ) FARM

) LE LIS BLANC

( ) OSKLEN

\section{CHEIRO 3:}

( ) MARIA FILÓ

( ) CANTÃO

( ) FARM

( ) LE LIS BLANC

( ) OSKLEN
CHEIRO 4:

( ) MARIA FILÓ

( ) CANTÃO

( ) FARM

( ) LE LIS BLANC

( ) OSKLEN

\section{3a PARTE: RESPOSTAS AO TESTE}

4 - Quantos cheiros acertou?

( ) 1 ( ) 2 ( ) $3($ ) 4 ( ) 5

5 - De quais lojas acertou o cheiro?

NENHUMA

（）CANTÃO （） FARM （）LE LIS BLANC （）MARIA FILÓ （）

6 - Ao sentir os cheiros apresentados, você (marque a opção que mais se aproxima à sua percepção):

( ) Conseguiu associar de imediato o cheiro à loja, pois é cliente da marca.

( ) Conseguiu associar o cheiro à loja, pois mesmo não sendo cliente já passou por ela algumas vezes e lembrou-se.

( ) Conseguiu associar o cheiro à loja, mas ficou confusa com a semelhança entre os cheiros.

( ) Não conseguiu associar o cheiro à loja, pois nunca entrou lá.

( ) Não conseguiu associar o cheiro à loja, pois nunca sentiu esse cheiro.

7 - Quando você entra em uma loja que tem seu cheiro próprio, qual das opções abaixo mais combina com você? (Marque apenas 2 opcões.)

( ) Adoro o cheirinho que fica na roupa!

( ) Não apenas reparo o cheiro, como também quero levá-lo para casa.

( ) Às vezes passo por uma loja que não conheço e entro por causa do seu cheiro. 
( ) Não reparo no cheiro. Estou apenas interessada nos produtos.

( ) Não reparo no cheiro, pois estou focada na liquidação.

( ) Acho o cheiro forte (ou enjoativo) e desnecessário.

8 - Que tipo de sensação o "cheiro da loja" Ihe desperta? (Marque até 3 opcões):

( ) Alegria

( ) Conforto

( ) Prazer

( ) Relaxamento

( ) Vontade de permanecer mais tempo

( ) Indiferença

( ) Dor de cabeça

( ) Outros.

Quais?

9 - Compraria o aromatizador de uma das lojas apresentadas para utilizá-lo em sua casa? Caso sim, de qual loja?

( ) Sim

$$
\begin{array}{ll}
\text { ( ) MARIA FILÓ } & (\text { ) LE LIS BLANC } \\
(\quad) \text { CANTÃO } & (\text { ) OSKLEN } \\
(\quad) \text { FARM } &
\end{array}
$$

( ) Não

10 - 0 que acha da estratégia das lojas aromatizarem seus pontos de venda? (Marque a opção que mais se aproxima do que você acha):

( ) Acho uma ótima estratégia, pois atrai os consumidores a entrarem no seu ponto de venda, tornando o ambiente da compra mais agradável.

( ) Acho uma estratégia eficiente, pois ajuda as lojas a reafirmarem a identidade e o conceito da marca.

( ) Acho que o cheiro, quando exagerado, pode causar mal estar.

( ) Não gosto, pois cheiros incomodam as pessoas que têm problemas respiratórios. 
11 - Idade:

( ) $18-25$ anos

( ) 26 - 35 anos

( ) $36-45$ anos

( ) $46-60$ anos

OBRIGADA POR SUA PARTICIPAÇÃO! 